\title{
Inflation Dynamics and its Sources in the Ottoman Empire: 1586-1913
}

\section{Hakan Berument \& Asli Gunay}

To cite this article: Hakan Berument \& Asli Gunay (2007) Inflation Dynamics and its Sources in the Ottoman Empire: 1586-1913, International Review of Applied Economics, 21:2, 207-245, DOI: 10.1080/02692170701189102

To link to this article: http://dx.doi.org/10.1080/02692170701189102

曲 Published online: 29 Mar 2007.

Submit your article to this journal $\pi$

III Article views: 122

Q View related articles $\sqsubset$

4 Citing articles: 1 View citing articles 


\title{
Inflation Dynamics and its Sources in the Ottoman Empire: 1586-1913
}

\author{
HAKAN BERUMENT* \& ASLI GUNAY**1 \\ *Bilkent University, Ankara, Turkey, ${ }^{* *}$ Middle East Technical University, Ankara, Turkey
}

\begin{abstract}
This study examines the dynamics and determinants of inflation in the Ottoman Empire during the 1586-1913 period. There are two possible reasons for inflation: fiscal expansion and monetary expansion, which could be generated through the debasement of local currency (Akçe). We used a set of political and structural variables in order to explain the change in inflation dynamics. In particular, we considered the war years, periods of Ottoman history that show different characteristics (the slow-down period, the recession period and the break-up period) and the period of constitutional monarchy. Moreover, we tested whether the inflation process was the same for each sultan and whether each sultan's behavior during the first year was different from the rest of his reign. The empirical evidence reported here suggests that war accelerated inflation as expected and fiscal expansion rather than the debasement of the Akçe was the main reason for inflation. Moreover, the slow-down, the recession and the break-up periods affected inflation positively; both fiscal expansion and the debasement of the Akçe were seen in these three periods as sources of inflation. While employing different inflationary policies during his reign, each sultan accelerated inflation in the first year of his reign by the debasement of the Akçe or by fiscal expansion. Last, the constitutional monarchy period had a significant positive effect on inflation although fiscal expansion, rather than the debasement of the Akçe, was the source of inflation during this period.
\end{abstract}

KEY WORDS: Inflation, debasement, fiscal expansion, Ottoman Empire.

JEL ClASSIFICATIONS: E31, H11, H30

\section{Introduction}

This paper studies the dynamics and determinants of inflation in the Ottoman Empire during the 1586-1913 period. Even though the sources of inflation could be numerous, we will consider two possible reasons for inflation; monetary expansion as a result of the generation of seigniorage revenue by debasing the local currency $(A k c ̧ e)$ and fiscal expansion. The reason for this concentration on 
monetary and fiscal variables is that other variables such as supply side shocks, which stem from weather conditions or trade restrictions, are unlikely to be persistent and are difficult to observe for a such a long period of time. We, then, used a set of political and structural variables in order to assess the interaction of inflation with these political variables.

We consider three main possible cases concerning the common notion of political intervention in an inflationary process. First, many wars were seen in the Ottoman period and financing a war means extra expenses. Hence, it could be interesting to examine the effects of war on the dynamics of inflation. Ferguson (1996) argues that war was inflationary in Germany during the First World War. Moreover, Bolbol (1999) finds that war was one of the main reasons for high inflation in Lebanon during the Civil War period. Similarly, our empirical results suggest that war accelerated inflation as was expected and fiscal expansion rather than the debasement of the $A k c ̧ e$ was the source of inflation.

The second case is the theory of Partisan Political-Business Cycle (PBC), initiated by Hibbs (1977), which deals with characteristic differences in the economic policies of governments according to their constituencies. According to this line of thought, governments apply fiscal and monetary policies to favor their constituencies and economic outcomes such as the level of output and inflation. These variables fluctuate as a function of the ideology of the party in power so that they will be re-elected. For example, Alesina \& Sachs (1988) show that the Republican Party in the USA has been relatively more concerned than the Democratic Party about inflation rather than output since the partisan theory suggests that Democratic voters will be more concerned about unemployment relative to inflation than Republican voters. Under the Democratic administrations, the deviation of output growth from the trend occurred mostly in the first half of the term, while the rate of growth of inflation was systematically different for the entire 4-year term. The Republican Party, however, tried to deviate inflation growth from the trend in the first half of their terms. That is, the real effects of new policies are stronger at the beginning of new administrations. Moreover, Alesina \& Roubini (1992) show that elections and changes in government in 18 OECD economies affect inflation. They find that inflation tends to increase immediately after elections and long run partisan differences in the inflation rate are seen.

The Ottoman Empire was governed by sultans rather than political parties and there was no election system. Not all administrations had the same preferences regarding the level of inflation because not everybody was affected by inflation in the same way. The differences in the preferences of supporters caused the differences in the behavior of each sultan. Hence, different processes were observed after the accession to the throne of each new sultan. These processes represent attempts by the sultans to prevent rebellions by the soldiers and urban population. For example, the major constraint against the application of policies to overcome the unfavorable fiscal environment was the janissaries in Istanbul, special soldiers paid in the local currency $(A k c ̧ e)$. For this reason, each sultan adopted different inflationary policies to gain the appreciation of his supporters and opponents in the first year of his reign. Therefore, we can examine how the Ottoman Empire shows the Partisan PBC by analysing each sultan's inflationary acts. Our results suggest that each sultan's reign showed different acceleration in inflation and policies for the debasement of the $A k c ̧ e$ and fiscal expansion were the main sources of inflation. Moreover, each sultan increased inflation in his 
first year on the throne as a result of the debasement of the Akçe or fiscal expansion.

We also took into account the different historical eras (the slow-down, the recession and the break-up periods) in Ottoman history in order to see the waves of inflation and the sources of inflation during those periods because each era showed different social, economic and political characteristics. Our results show that the slow-down, the recession and break-up periods affected inflation positively and the debasement of the $A k c ̧ e$ or fiscal expansion were the main reasons for inflation.

The third case analyses the effects of the fractionalized governments (coalition or minority governments vs majority governments) on their inflationary policies. More fractionalized and more polarized governments (differences in ideological preferences) were seen in the constitutional monarchy period than in the absolute monarchy period. They faced greater difficulties in coordinating action over fiscal and monetary policies. Roubini \& Sachs (1989) argue that it is more difficult for coalition governments to raise taxes and decrease government expenditures. Hence, a more fractionalized government causes higher budget deficits and inflation. Coalition is one of the main factors that leads to chronic and persistent inflation (Arce \& Daniel, 1994). Minority parties and coalition governments are more constrained by electoral concerns, so they try to satisfy influential constituencies and special interests in order to be re-elected (Haynes \& Stone, 1990). Hence, the debasement of the $A k c ̧ e$ and fiscal expansion caused acceleration in inflation, resulting in unfavorable fiscal situations in the constitutional monarchy era. Our empirical evidence suggests that the period of constitutional monarchy had a positively significant effect on inflation. However, anti-debasement acts rather than debasement were seen, and fiscal expansion was the main reason for increasing inflation in this period.

Pamuk (1997) argues that fiscal and monetary conditions in the Ottoman Empire emerged as the primary explanation for the debasement of the Akçe during the 17th century. The Ottomans faced severe fiscal pressures and struggled with rising military expenditures and the adverse consequences of inflation during this period. One of the main responses to this situation was currency debasement, which provided temporary financial relief but also contributed to a new momentum in price increases. Although the results of his study resemble ours, our research differs from his on three accounts. First, he did not focus on the dynamics of inflation analyses as deeply as we did; that is, he did not explain waves of inflation according to the important political structural variables. Second, Pamuk (1997) showed that inflation had adverse consequences on state finances. However, he only analysed the debasement of the $A k c ̧ e$ as a source of state finances that caused inflation, whereas we also looked at the fiscal expansion as another main policy for inflation and examined the effects of fiscal expansion on inflation. Third, he examined only the 17th century for his debasement analyses, while we took into account the historical eras of the Ottoman Empire (the slow-down, the recession and the break-up periods) and the constitutional monarchy period in our analysis.

Our results show that debasement was one of the main reasons for the acceleration of inflation in the 17th century, which confirms Pamuk's (1997) results. However, we proposed that fiscal expansion was another main explanation for the variability of inflation during this period. This article provides evidence that the debasements were the results of fiscal difficulties and that the state benefited 
in the short run. There was no such long-term strategy during this particular period. Similarly, when we analyse each sultan's period separately, we can see that they did not follow the same policy although debasement occurred in all three historical eras in Ottoman history, but not during the period of constitutional monarchy.

This study extensively analyses inflation dynamics with the longest historical data series that is available for the Ottoman Empire. In addition, we examined the effects of different social and political situations on inflation movements. Therefore, these explanations may contribute to an understanding of why fiscal deterioration and inflation arose in the Ottoman Empire.

Before analysing the inflation dynamics, it might be useful to present a brief summary, focusing on the path of inflation over this period to throw light on Ottoman economic history. Pamuk (2000) analysed the monetary history of the Ottoman Empire and this study established the basic trends in prices in Ottoman history. Figure 1 shows the annual values of the overall price index, which combines the food prices obtained from the account books of pious foundations with the prices of non-food items. The vertical axis is given in log scale so that the slope of the line indicates the rate of change of nominal prices. These results indicate that prices increased approximately 300 fold between 1469 and the First World War. This overall increase corresponds to an average increase of $1.3 \%$ per year for the entire period.

The indices show that Istanbul experienced a significant wave of inflation from the late 16th century to the middle of the 17th century when prices showed a five-fold increase. This is the period usually associated with the Price Revolution of the 16th century, which has been the subject of one of the most enduring debates in European historiography and more recently in the

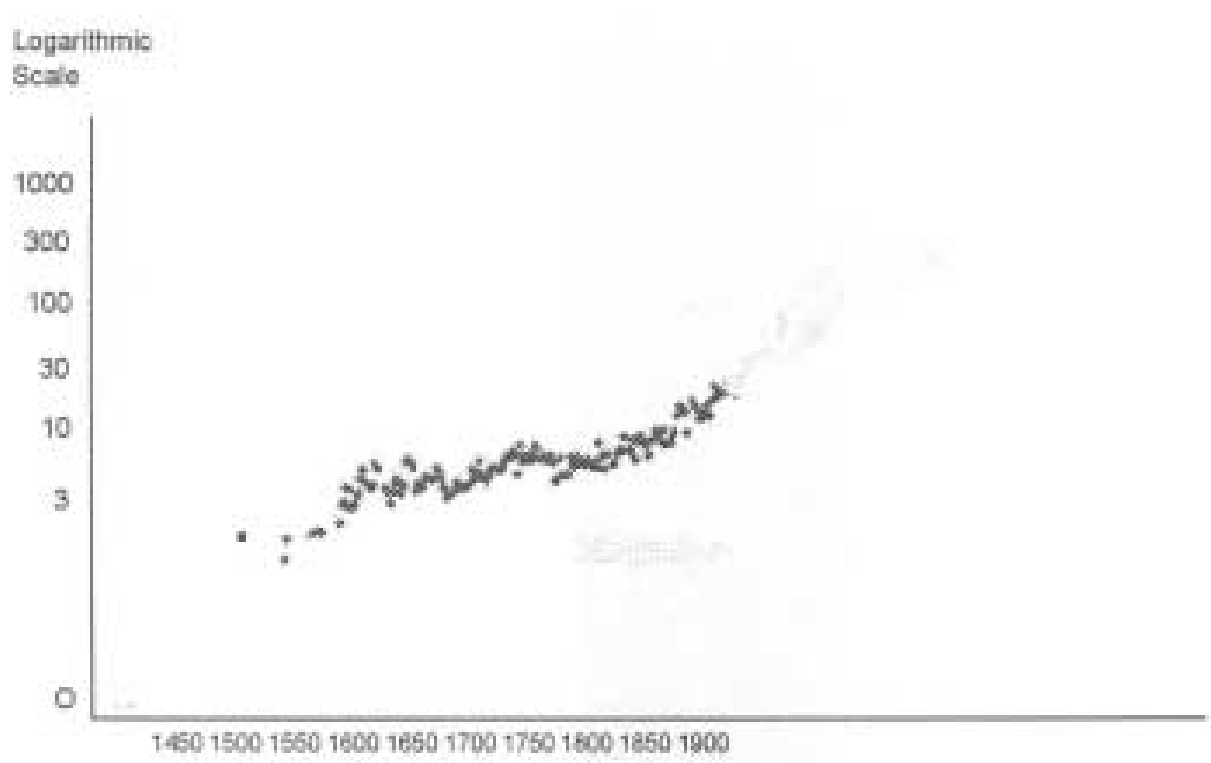

Source: Pamuk, 2000; A Monetary History of the Ottoman Empire, p. 236.

Figure 1. Price index for Instanbul, 1469-1914 for Akçe: $1469=1.00$. 
historiography of the world economy. That European prices, expressed in grams of silver, increased by more than $100 \%$ (and in some countries, by more than $200 \%$ ) from the beginning of the 16th century to the middle of the 17th century has been well established and widely accepted (Braudel \& Spooner, 1967). Evidence shows that after 1568 (and possibly even earlier) price increases were caused by an expansion in the money supply arising from the inflow of New World treasure into Spain (Schumpeter, 1954). After establishing that large increases in food and raw materials prices did take place, Barkan (1975) argued that these trends were imported into the Ottoman economy through trade with Europe via the Mediterranean. The indices also show, however, that a much stronger wave of inflation began late in the 18th century and lasted into the 1850s, during which time prices increased 12-15 fold. Most of the later increases were associated with debasements of the Akçe, which began in the 1780s and accelerated during the reign of Mahmud II (1808-1839). The highest rates of debasement of $A k c ̧ e$ in Ottoman history took place during the reign of the reformist and centralizing sultan, Mahmud II. He was able to abolish the janissaries in 1826; therefore, a major constraint in the way of debasements of Akçe was lifted. In contrast, the overall price level was relatively stable between 1650 and 1780 as well as from 1860 until the First World War.

The rest of this paper is organized as follows. The data is described in the second section. The methodology is discussed and empirical evidence is reported in the third section. The fourth section presents our conclusions.

\section{The Consumer Price Index for Istanbul 1469-1918}

The data for the Consumer Price Index for Istanbul are the first of its type for the Middle East; in fact, for anywhere in the non-European world. It is considered to be the most detailed and reliable for these four and a half centuries (1469-1918). It was prepared by Şevket Pamuk and published by the Turkish State Institute of Statistics (SIS) in 2000. The data are available in Tables 1-3. Table 1 shows the Consumer Price Index, which combines the food prices obtained from the account books of pious foundations (vakif) with the prices of non-food items. Table 2 presents the annual silver content of the $A k c ̧ e$. Pamuk constructed price indices (expressed in grams of silver) which were obtained by multiplying the value of the price index by the silver content of the Ottoman currency for the same year. These indices are shown in Table 3.

The prices for Istanbul were calculated utilizing a large number of Ottoman archival documents. They were basically extracted from data on the prices of standard commodities: food and non-food items. Three separate price indices were constructed for food items according to the type of institution involved in consumption, whereas only one price index was constructed for the non-food items. One of the food price indices is based on the account books and prices paid by the many religious foundations, both large and small, and their soup kitchens (imaret). The second food price index is based on the account books of the Topkapi Palace kitchen. The third utilizes the officially established price ceilings (narh) for the basic items of consumption in the capital city: Istanbul.

Standard commodities were used for these price indices in order to minimize the effects of quality changes. Each of these food indices includes the prices of 10-12 main consumption items. These are as follows: flour, rice, 


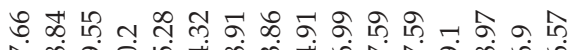

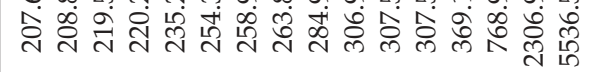

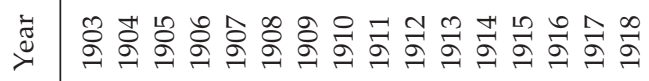

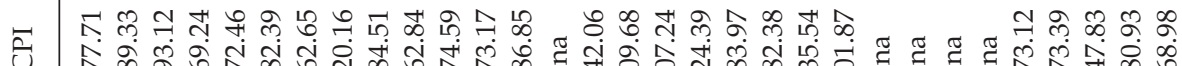

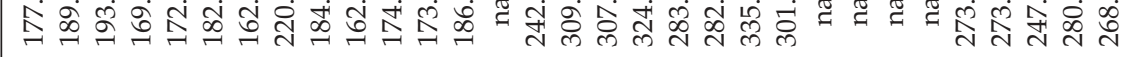

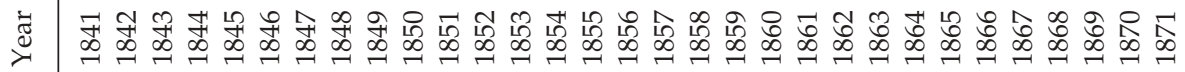

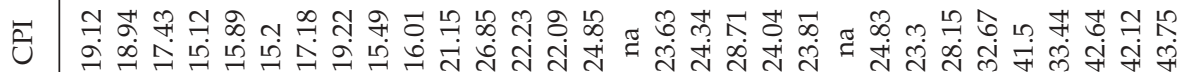

$\overline{.}$

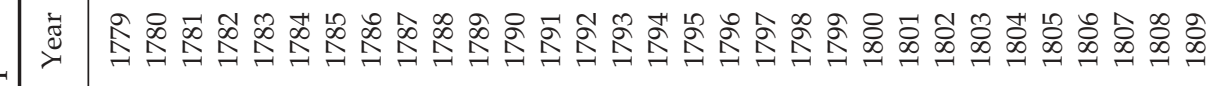

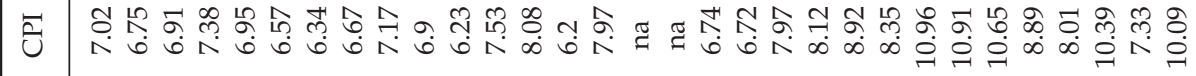

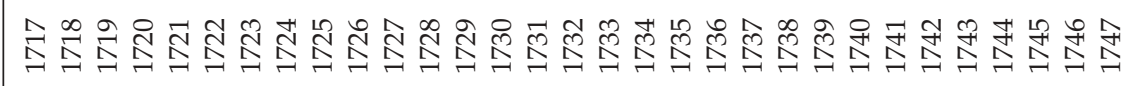

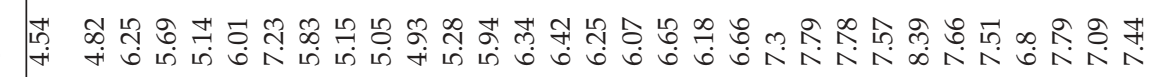

ن

U艹

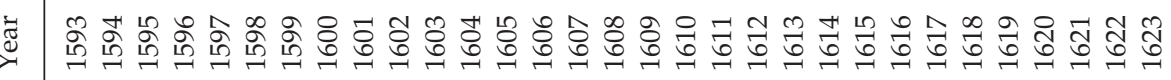

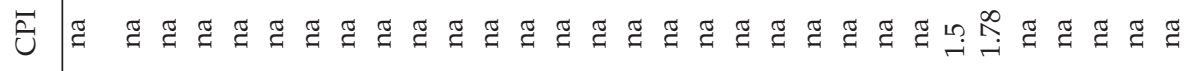

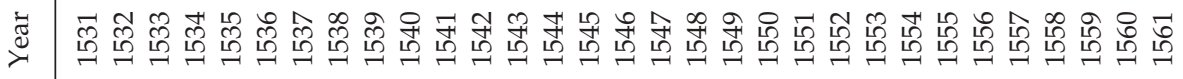

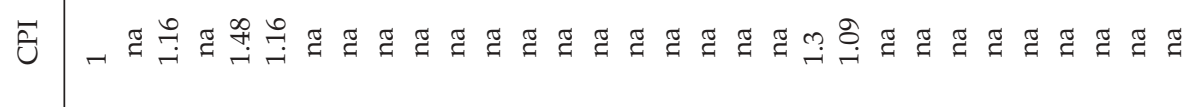

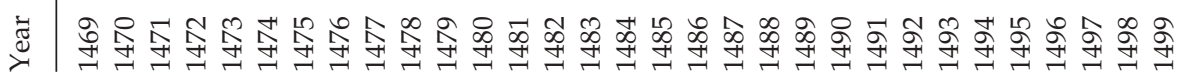




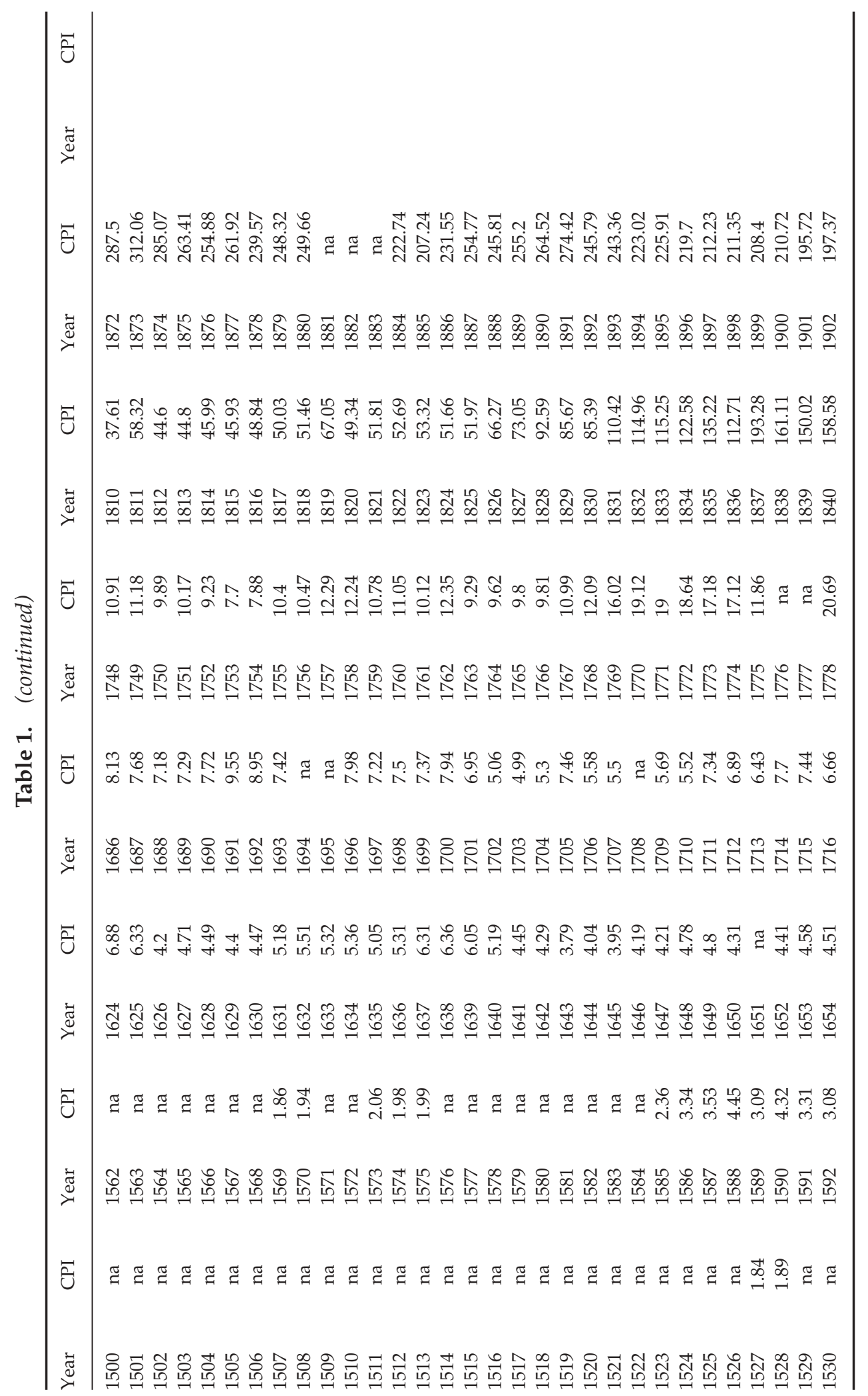




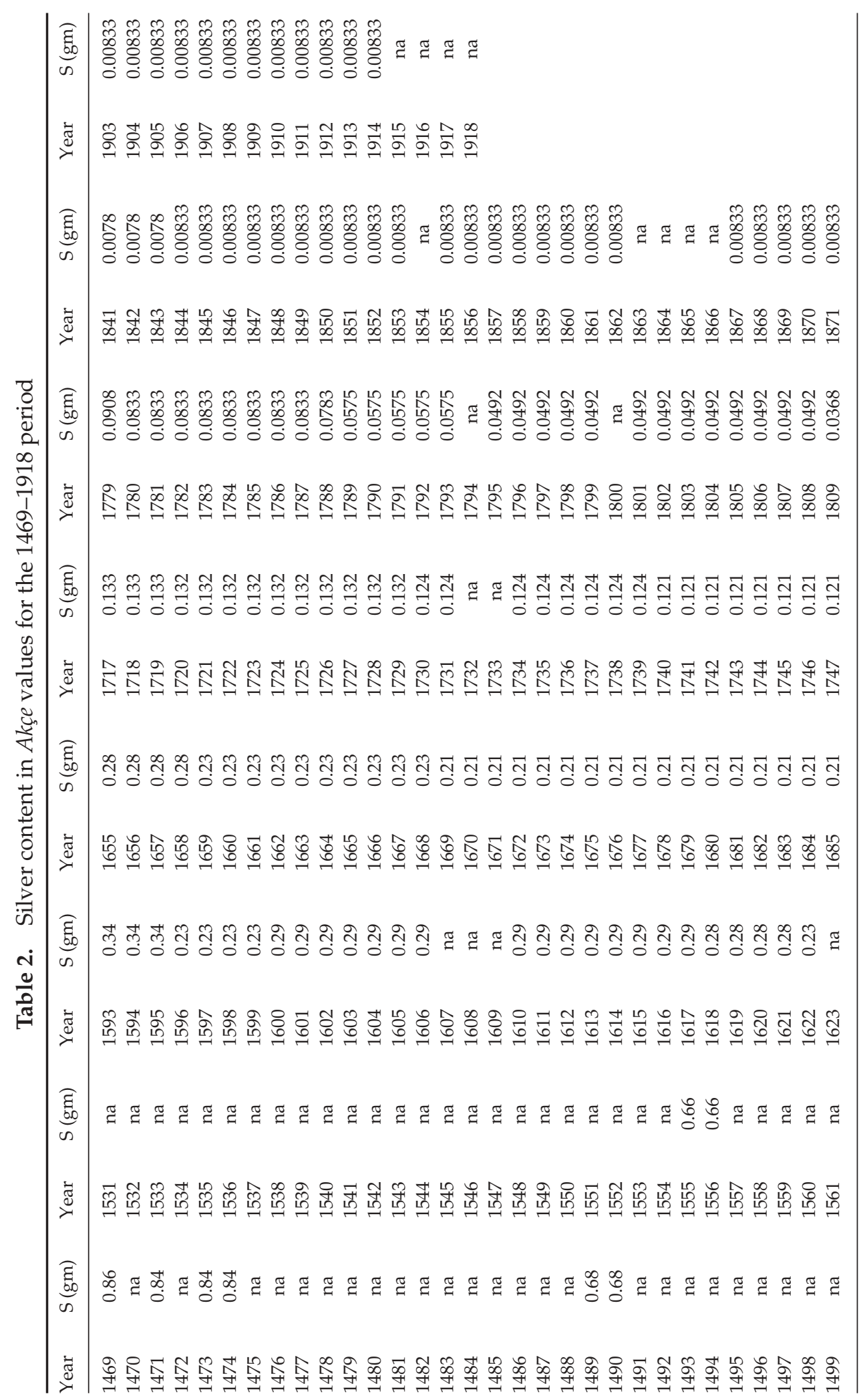




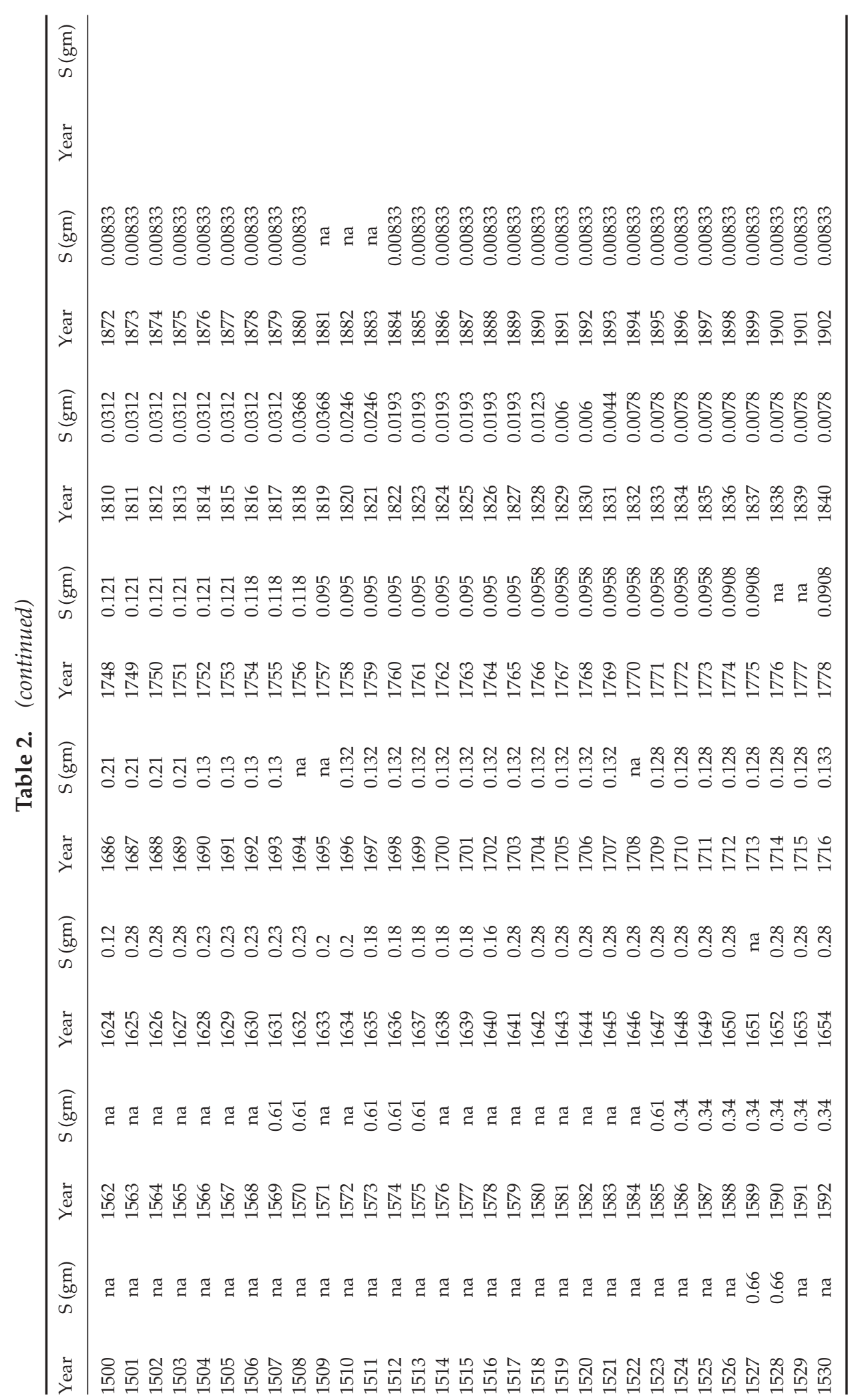




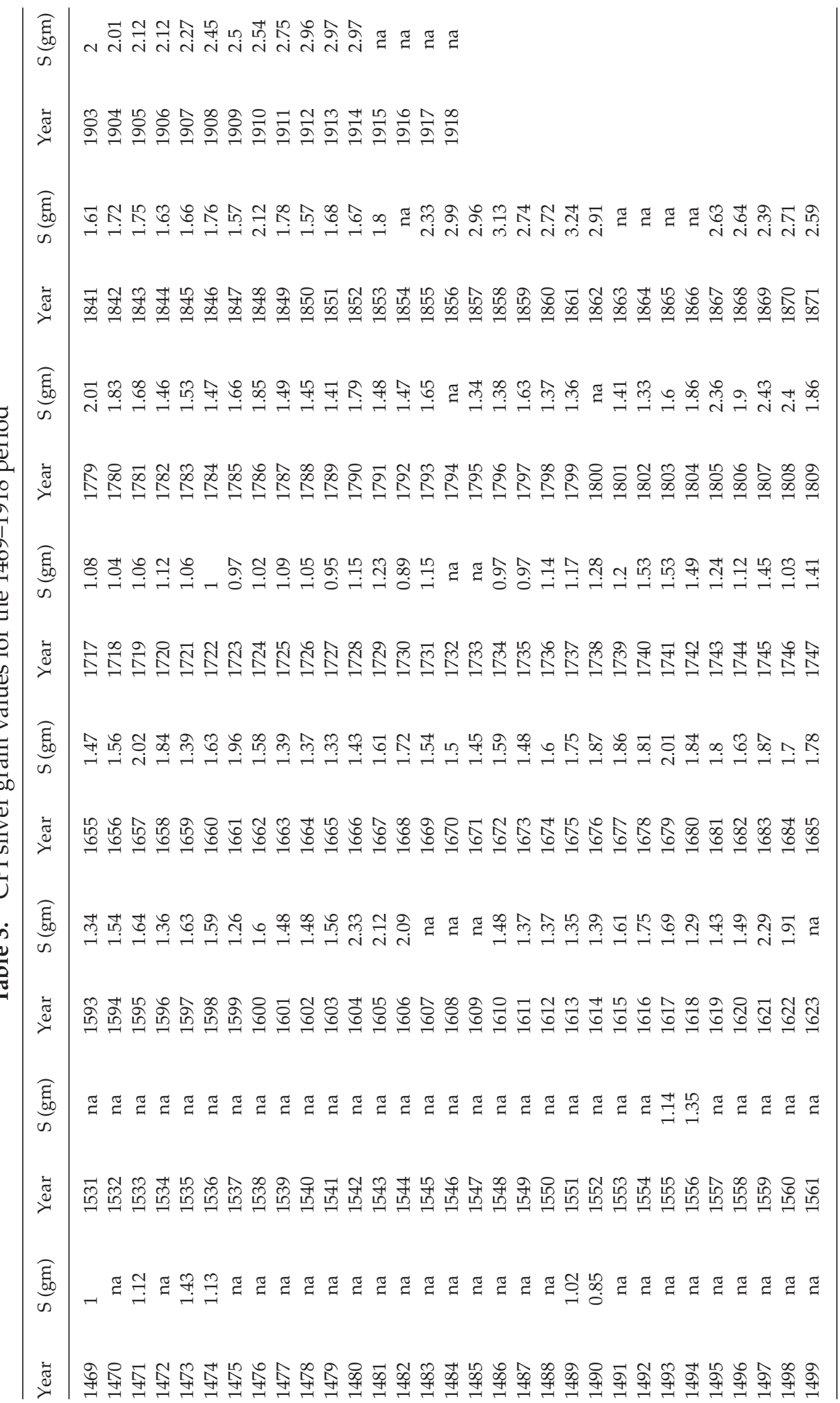


Inflation Dynamics in the Ottoman Empire 217

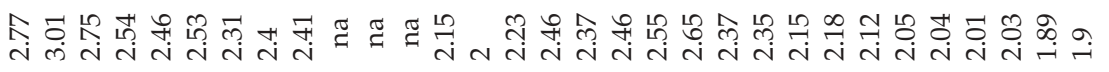

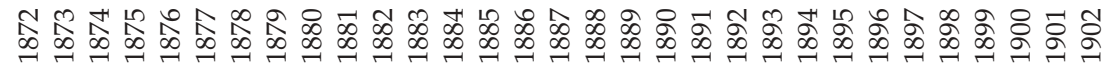

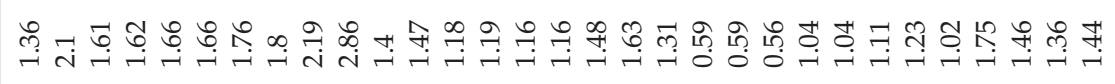

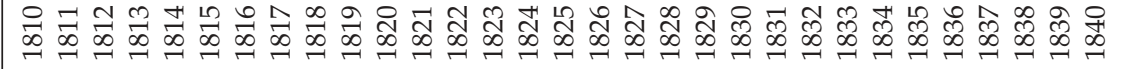

菅

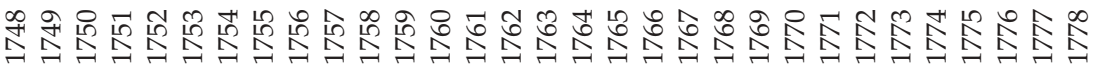

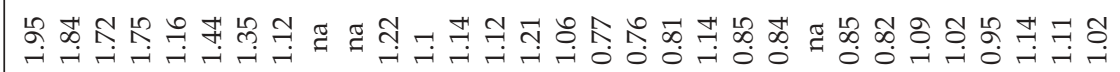

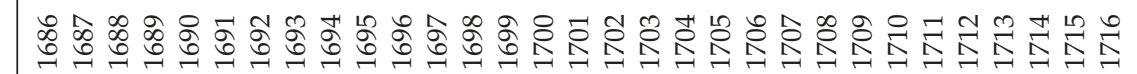

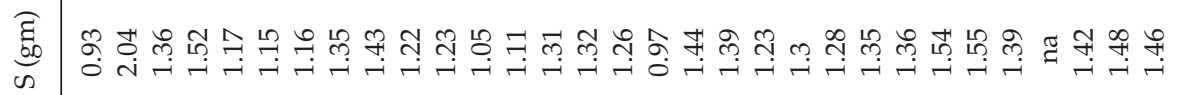

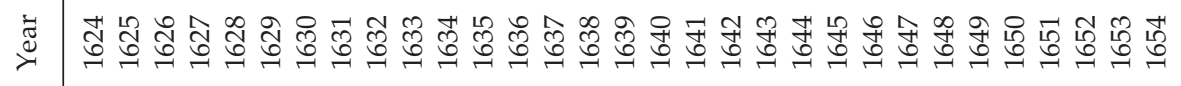

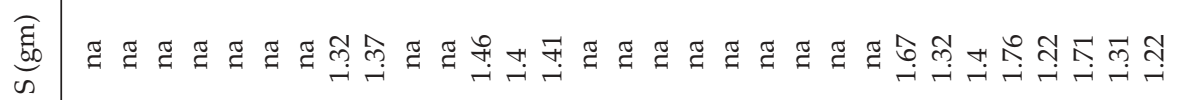

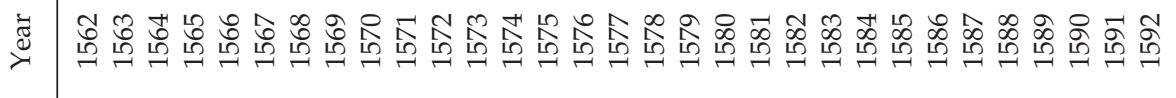

అ్

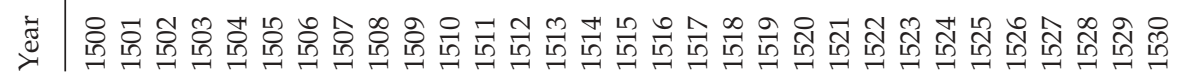


honey, cooking oil, mutton, chick peas, lentils, onions, eggs, sugar (for the palace only), coffee (as of the 17th century for the palace and the 18th century for the religious foundations), and olive oil for burning. Among these, flour, rice, cooking oil, mutton, olive oil and honey provided the most reliable long term series and represented the greatest proportion of the food budget. The prices of non-food items were obtained from a variety of sources, most importantly the palace account books. The commodities considered are soap, wood, coal and nails.

The weight of food items in the overall indices was fixed between $75 \%$ and $80 \%$, based on the available evidence regarding the budget of an average urban consumer. The weight of each commodity in the overall index was based on the shares of each in the total expenditures of the respective institutions. Greater weight was given to the indices based on the prices paid by the soup kitchens and, more specifically, the pious foundations because the palace and the narh prices might be considered as official or state controlled prices. The weights of the individual commodities were kept constant as long as they were included in the index.

\section{Empirical Evidence}

Time series analysis developed various tools to capture the dynamics of a series. The autoregressive (AR) method estimation for univariate series is one of the most commonly used tools to capture the dynamics of the series. In this paper, we assess whether the dynamic path of inflation, which is captured by an auroregressive process, is interrupted by a set of exogenous variables. If so, the transfer function analysis can be used and the following model can be estimated in order to capture the effects of political and structural changes on the dynamics of inflation (Enders, 2000, p. 239):

$$
\pi_{t}=\beta_{0}+\sum_{i=1}^{p} \beta_{i} \pi_{t-1}+\gamma Z_{t}+\varepsilon_{t}
$$

where $\pi_{t}$ is the inflation rate, $p$ is the lag order, $Z_{t}$ is a vector which contains the political and structural variables that may affect the behavior of $\pi_{t}$, and $\varepsilon_{t}$ is the error term at time $t$. Basically, we intend to assess whether $Z_{t}$ affects the dynamic path of inflation, which is captured with the lag values of the inflation itself. Here, $\gamma$ is the coefficient of capturing the effects of political and structural situations on inflation dynamics. If we find that the estimated coefficient of $Z_{t}(\gamma)$ is statistically significant; that is, if we can reject the null hypothesis that $\gamma=0$, then we claim that the particular political and structural variable that will affect the dynamics of $\pi_{t}$.

In order to conduct this study, a benchmark model is needed. An autoregressive model is estimated for the inflation process. First, inflation is calculated as the change in the logarithm of two consecutive price indices. Then, inflation was regressed on its own lags with a constant term. In order to determine the optimum lag order, the final error criteria is used. This method determines the optimum lag order such that the residual term is no longer autocorrelated. The first four lags were used to account for the dynamics of inflation, indicating the AR(4) process. Hence, inflation was regressed on its four lags with the constant term 
and the results are presented in Table 4 in column I of panel A. The data set on price indices calculated by Şevket Pamuk covers the period between 1469 and 1918, but we started the sample from 1586 because of the frequency of missing observations and adopted the AR(4) process for inflation. We ended the data in 1913 to avoid the hyperinflation of the First World War years. In addition to lag values, inflation was also regressed on some political and structural variables, the coefficients of which account for the changes in the dynamics of inflation, not in inflation itself.

Being involved in a war requires extra expenses. Therefore, we tested whether the policies adopted during the war years in order to struggle with military expenditures caused inflation. In order to capture the war years, a dummy variable was designed. Figure 2 plots the inflation and the war periods as shaded areas. Visual inspection of the figure suggests that short lived wars, in particular, were associated with higher inflation. For long lasting wars, the inflation was not persistent despite the beginning of the war periods being inflationary. The war variable was added to the benchmark model (taking the value of one if there was war in this year and zero otherwise). The empirical evidence suggests that the war years accelerated inflation. However, the coefficient of the war variable is not statistically significant. $^{2}$ This results are presented in Table 4 in Column II of Panel A.

The military strength of the Ottoman Empire caused heterogeneity of tax revenue in the different regions of the Ottoman Empire to cover government spending requirements. The loss of some portion of land might dictate the government's fiscal and monetary setting. These two factors might determine the inflation level. We consider inflation in three different historical eras: the slow down (1586-1699), the recession (1700-1792) and the break up (1793-1913). Figure 3 plots the inflation with the segmentation of the three eras taken into consideration. However, the visual inspection of the figure does not suggest any clear evidence that the inflation was higher for any of the three periods when compared to the others. Thus, three dummy variables for the three different historical eras of the Ottoman Empire were introduced. Inflation was regressed against its four lags and the three dummy variables. However, the constant term was not included in the regression. The estimates of parameters are presented in Table 4 in column III of panel A. The empirical evidence reveals that the slow-down, the recession and the break-up periods affected inflation positively. However, the increasing trend of inflation was highest in the break-up period, which was the worst period of the empire and lowest in the recession period. Even though the coefficient of the break-up period was statistically significant, the coefficient was not significant for the recession period. In order to test whether each period had different inflationary policy, the $F$-test can be performed. The F-statistics value is 0.15 , so we cannot reject the hypothesis that inflationary policy was the same in each period.

A change of sultans can be taken as another explanatory variable for inflation dynamics since each sultan had different economic policies for managing the economy. Therefore, we tested whether the different policies of each sultan caused acceleration in inflation differently. Figure 4 shows the inflation during the reign of each sultan. Visual inspection does not suggest that inflation differs with different sultans. Each sultan's period dummy variable was designed specifically to capture the effect of his reign on inflation. All of these dummy variables were added to the benchmark model. The empirical results are presented in Table 4 in column IV of panel A. The estimates suggest that the periods of Sultans Ahmed I, Murad IV, Osman III, Mustafa IV, Mahmud II and Mehmed Resad V showed 


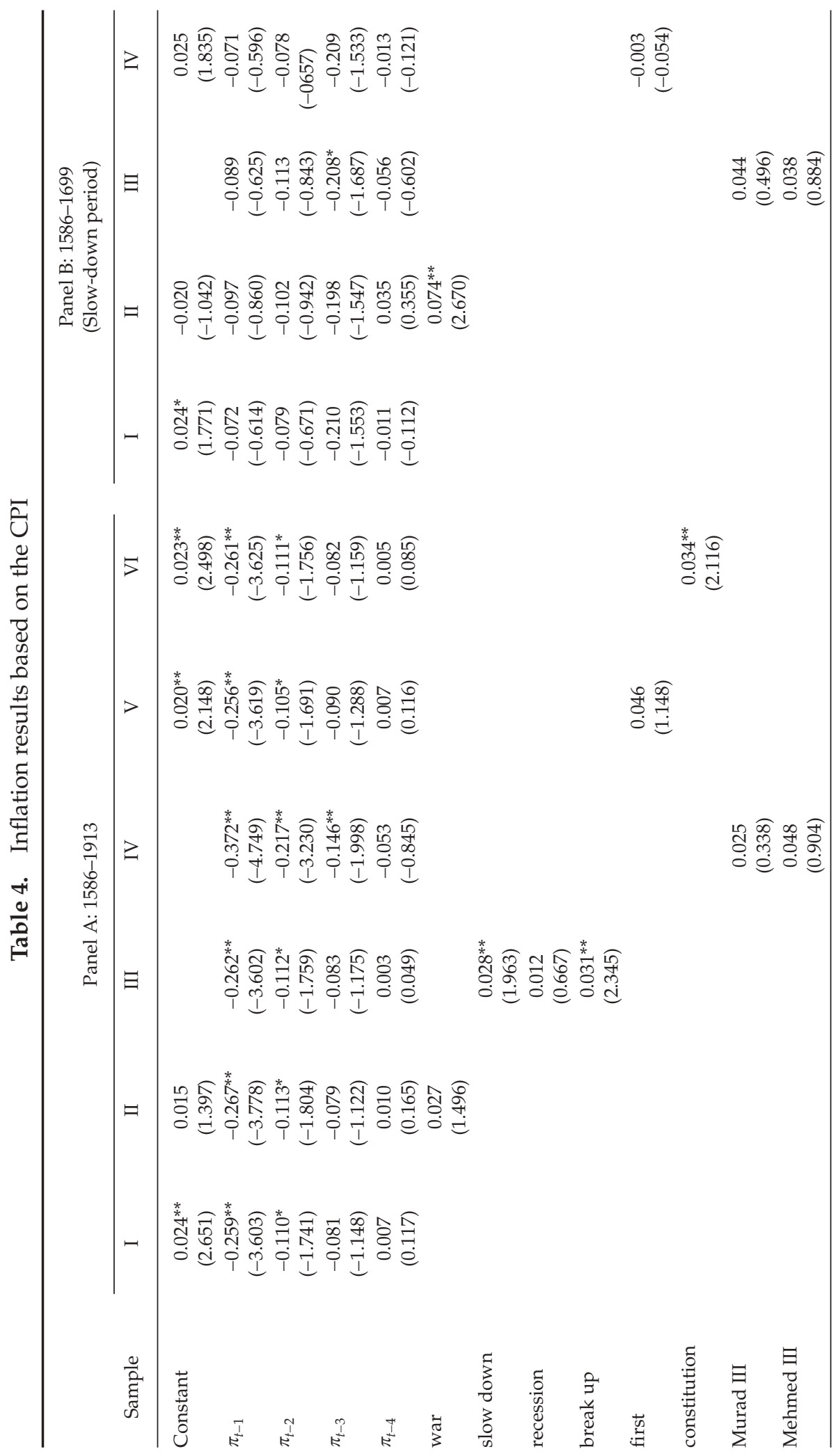




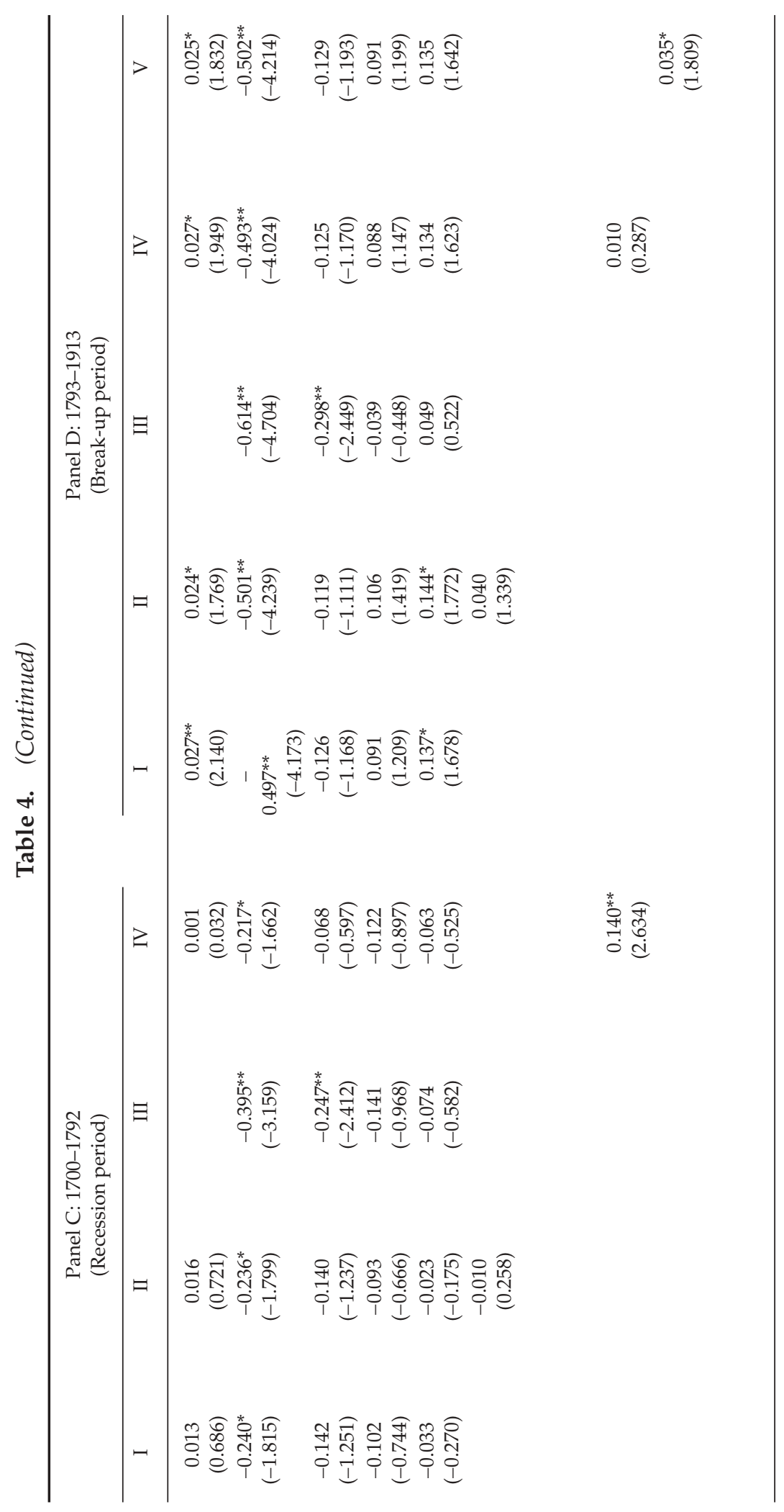




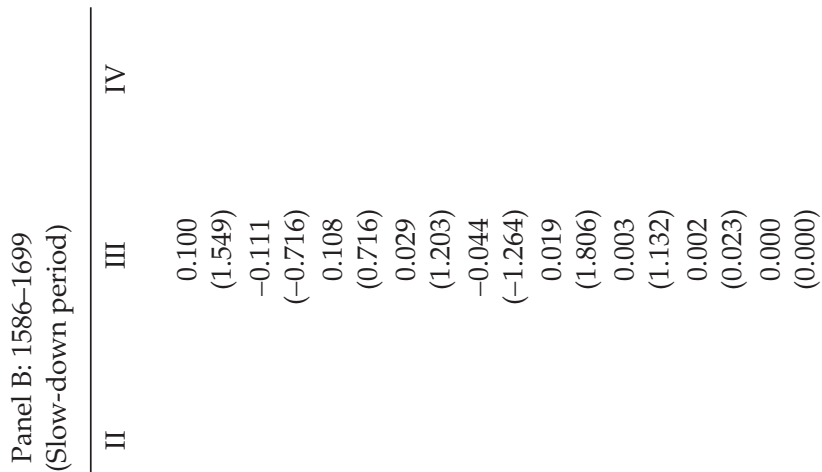

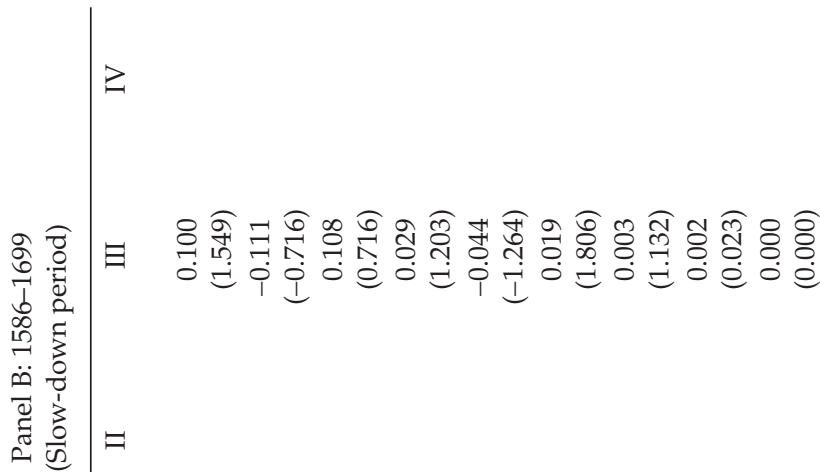

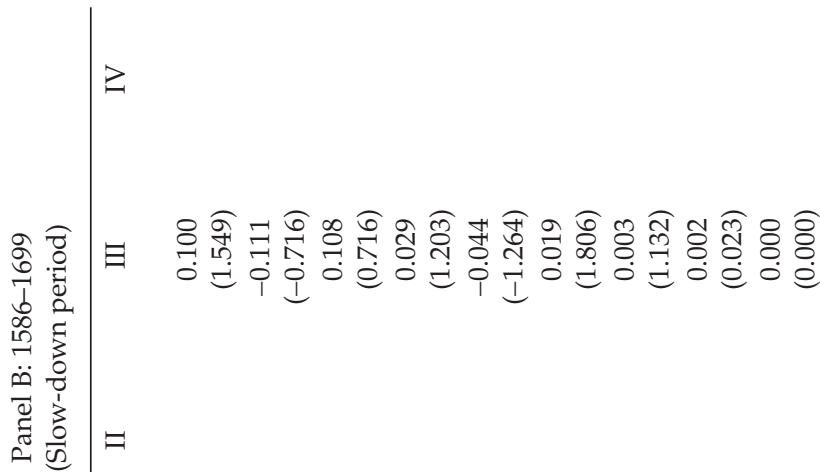

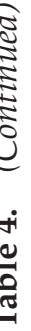

5

|

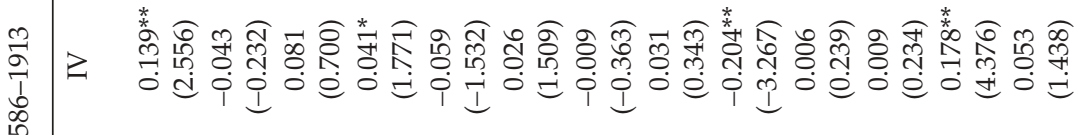

$\stackrel{\infty}{n}$

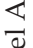

है

目

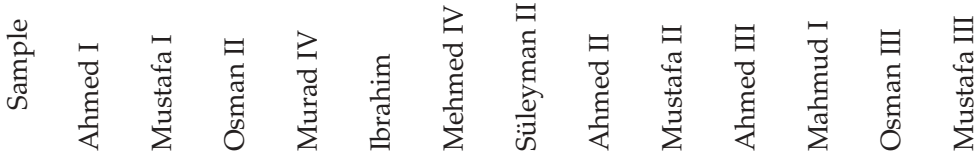


Inflation Dynamics in the Ottoman Empire 223

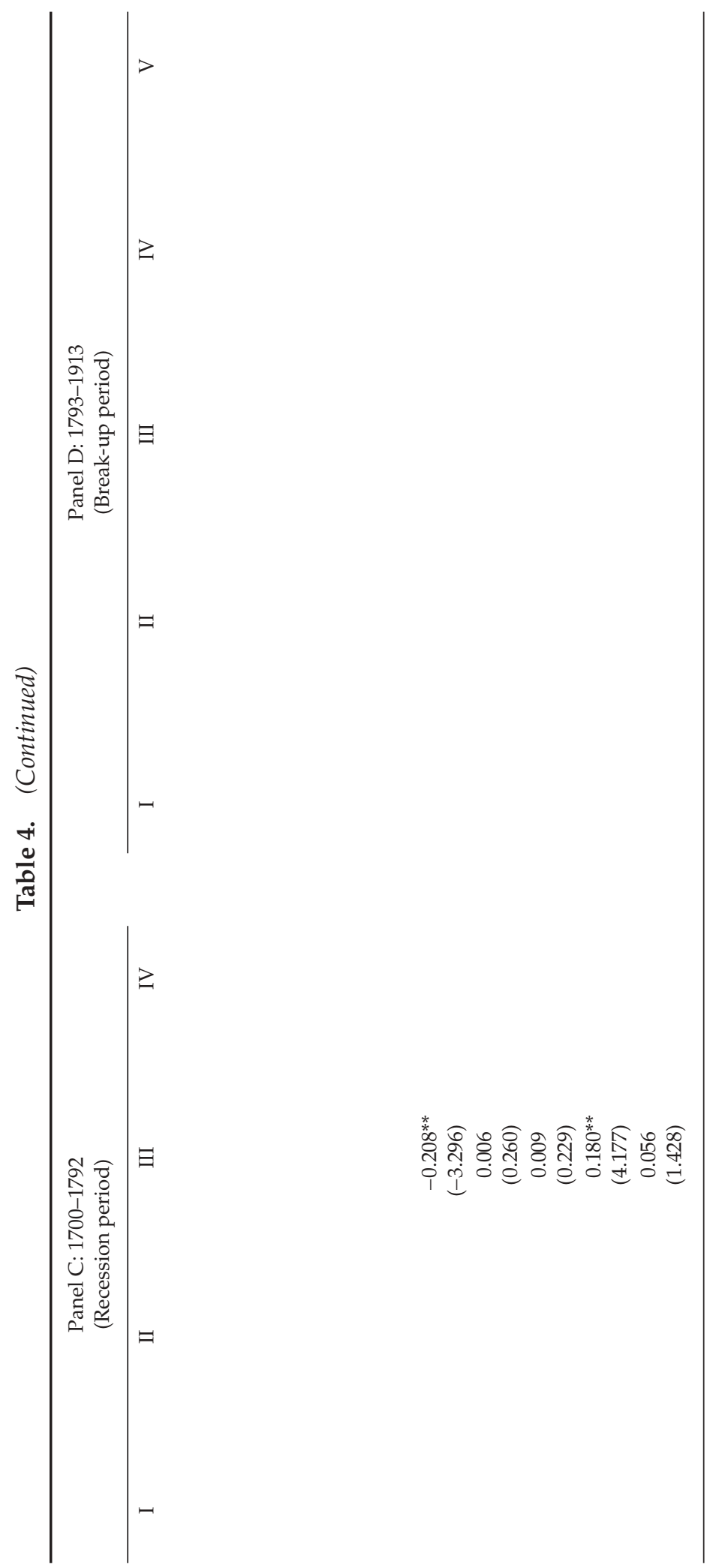




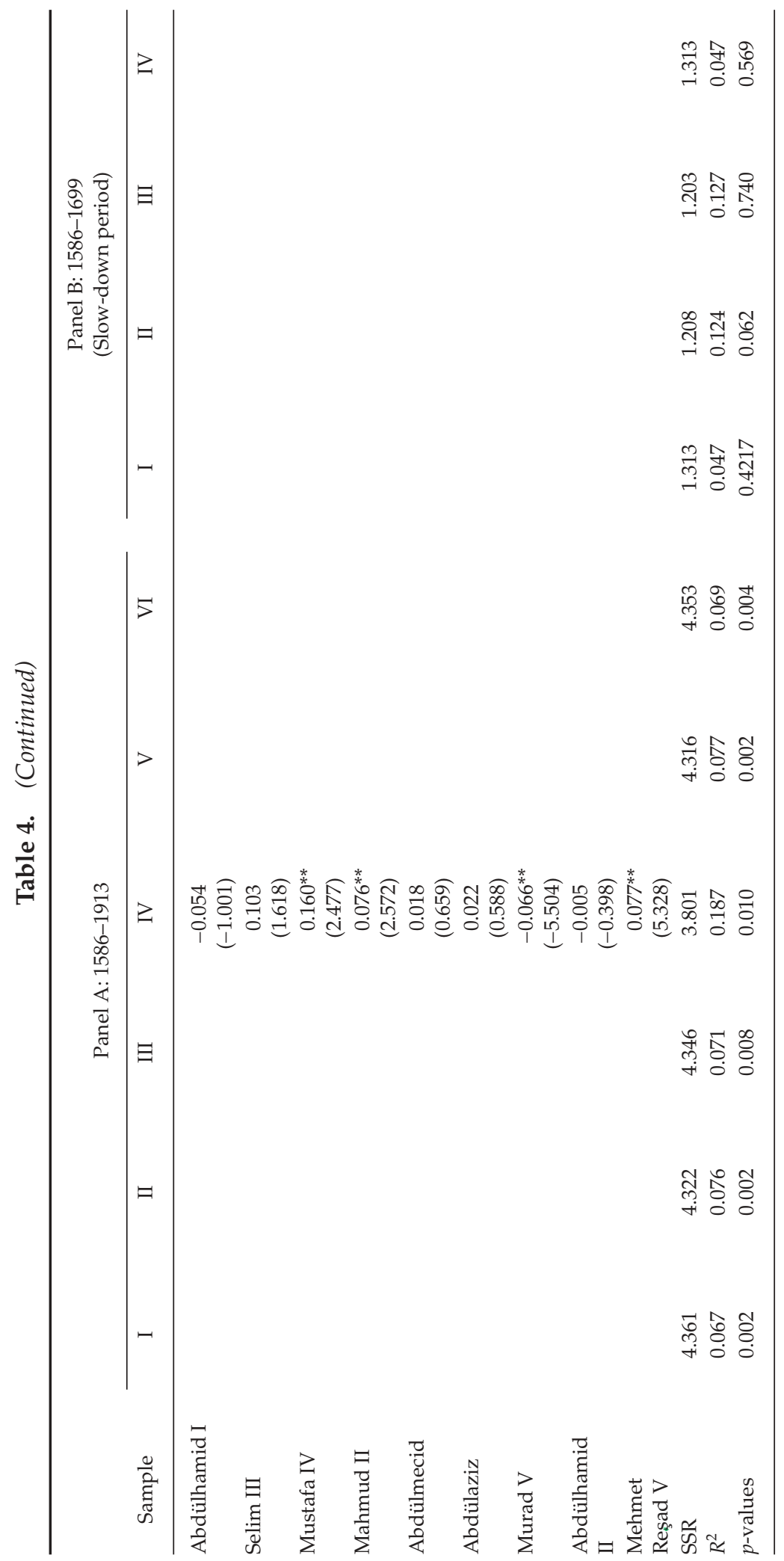


Inflation Dynamics in the Ottoman Empire 225

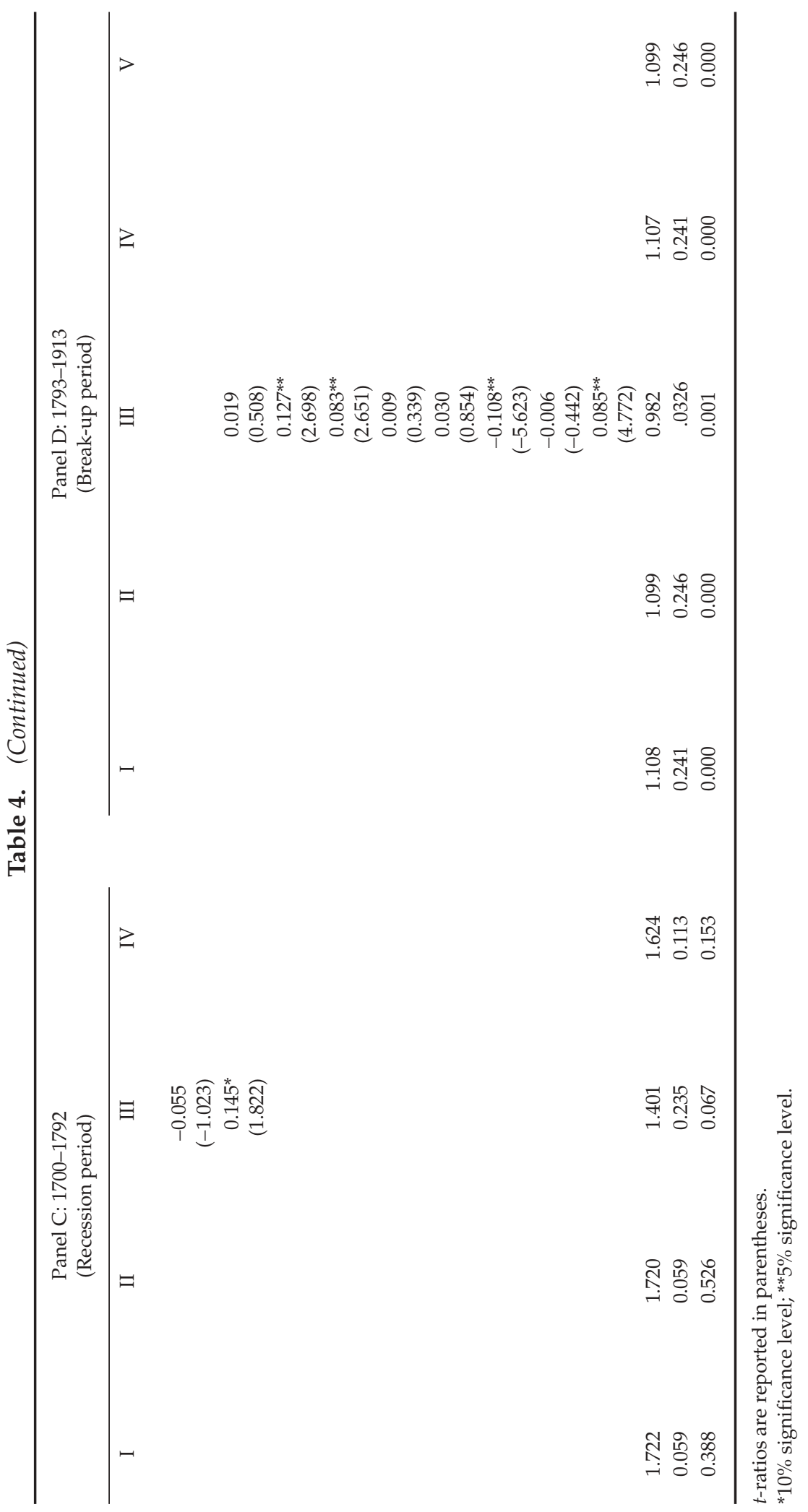




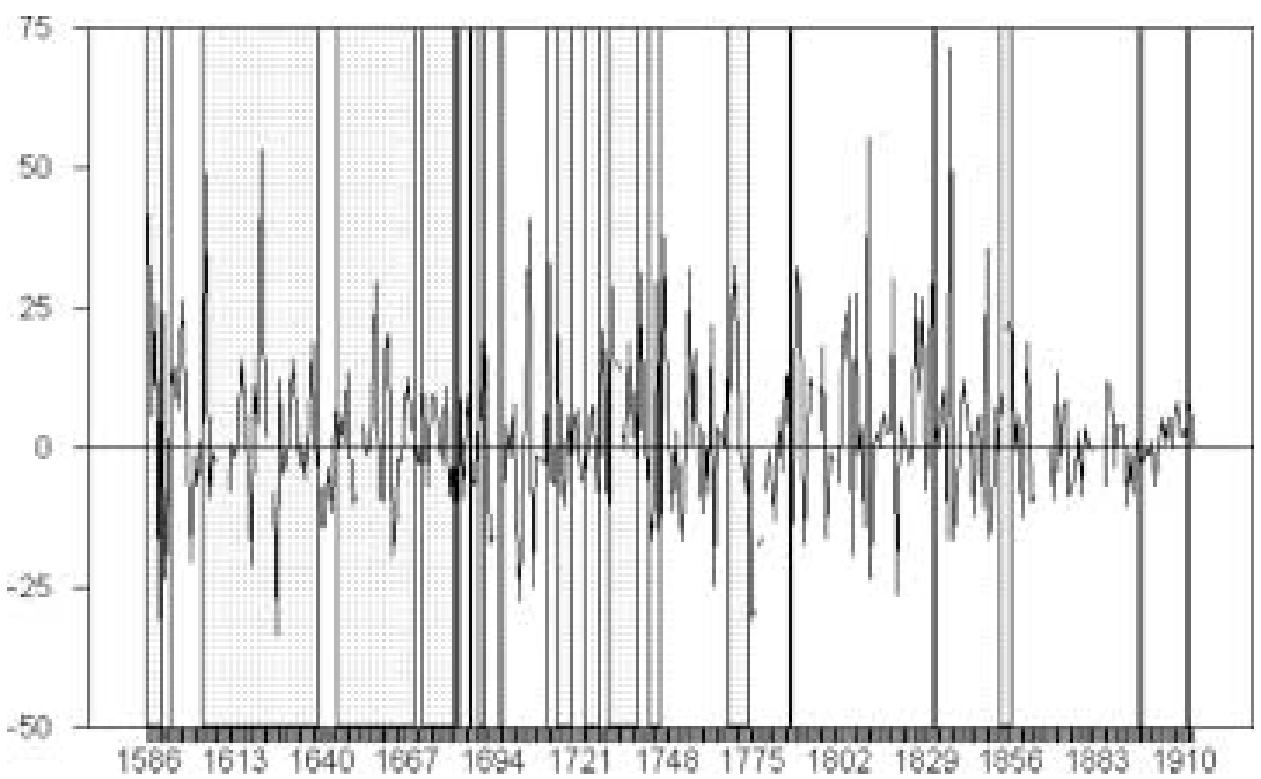

Figure 2. Inflation and war periods.

Notes: *The shaded areas show the following wars: 1578-1590, Ottoman-Iran War; 1593, OttomanHabsburg War; 1603-1639, Ottoman-Iran War; 1645-1669, Crete War; 1672-1681, OttomanPoland-Russia War; 1683, Ottoman-Austria War; 1687, Ottoman-Austria War; 1690-1691, Ottoman-Austria War; 1696-1697, Ottoman-Austria War; 1711, Prut War; 1714-1718, OttomanAustria War; 1723-1727, Ottoman-Iran War; 1730-1732, Ottoman-Iran War; 1733-1739, OttomanAustria-Russia War; 1743-1746, Ottoman-Iran War; 1768-1774, Ottoman-Russia War; 1787, Ottoman-Russia War; 1832, Egypt War; 1853-1856, Crimea War; 1896-1897, Ottoman-Greek War; 1911-1912, Trablusgarp War.

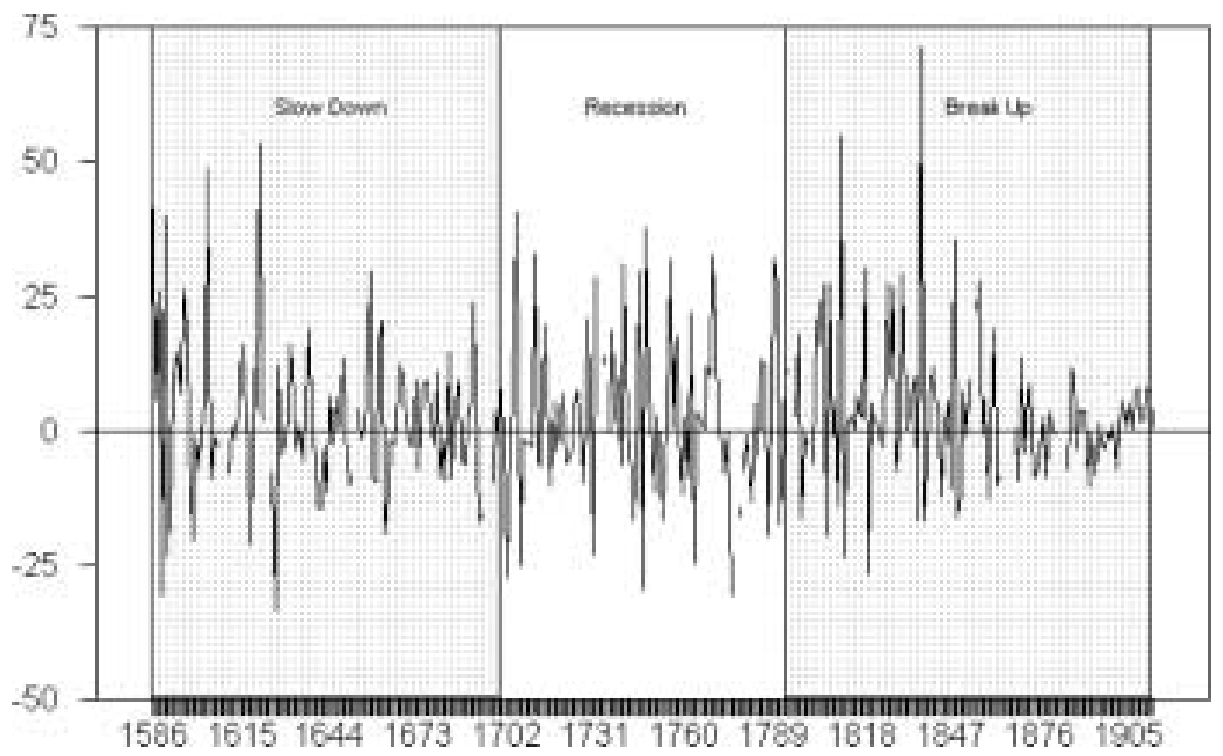

Figure 3. Inflation and three identified periods.

Notes: *The following periods are represented: 1586-1699, slow-down period; 1700-1792, recession period; 1793-1913, break-up period. 


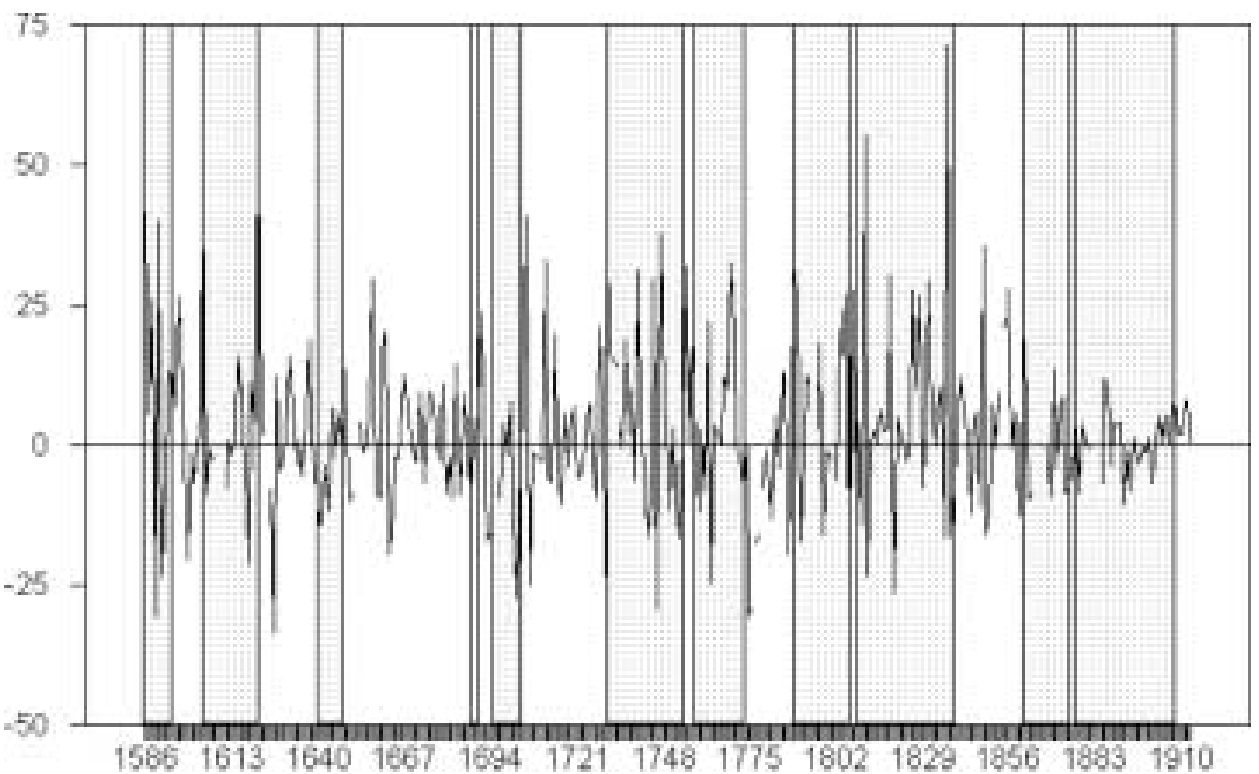

Figure 4. Inflation and sultan's periods

Notes: *Each area represents the period of a sultan's reign: 1575-1594, Murad III; 1595-1603, Mehmed III; 1604-1617, Ahmed I; 1618, Mustafa I; 1618-1621, Osman II; 1624-1639, Murad IV; 1640-1648, Ibrahim; 1649-1687, Mehmed IV; 1688-1690, Süleyman II; 1691-1694, Ahmed II; 1695-1703, Mustafa II; 1704-1730, Ahmed III; 1731-1754, Mahmud I; 1755-1757, Osman III; 1758-1773, Mustafa III; 1774-1788, Abdülhamid I; 1789-1806, Selim III; 1807-1808, Mustafa IV; 1809-1839, Mahmud II; 1840-1860, Abdülmecid; 1861-1875, Abdülaziz; 1876, Murad V; 1877-1908, Abdülmecid II; 1909-1918, Mehmet Reşad V.

statistically significant increasing movement in inflation. The highest acceleration in inflation was seen in the Sultan Osman III period. However, the periods of Sultans Mustafa II and Murad $V$ showed statistically significant deflationary movements and the highest deflationary process was seen in the Sultan Mustafa II period. The F-test was performed in order to determine whether each sultan had different inflationary acts. The result of the F-test was 1.96 , which suggests that each sultan utilized different inflationary acts at the $5 \%$ statistically significant level.

Each sultan may prefer to have more expenses during the first year of his reign since he wants to prevent rivals gaining popularity and power and thus stays on the throne longer. He may also prefer to apply favorable fiscal and monetary policies to win the good will of soldiers, supporters and opponents. Hence, we test whether the first year policies of each sultan were possible reasons for inflation dynamics. In order to capture this, a dummy variable was designed and the regression result is presented in Table 4 in column $\mathrm{V}$ of panel $\mathrm{A}$. The empirical evidence suggests that the first year policies of sultans affected inflation positively. However, the first-year coefficient is not statistically significant.

In order to explain the effect of government policies on inflation during the period of constitutional monarchy, a dummy variable was constructed and added to the benchmark model. This is related to the effects of fractionalized governments on inflation. More fractionalized governments face higher budget deficits and greater difficulties in coordinating inflationary action in order to finance deficits. 
The results, shown in Table 4 in column VI of panel A, indicate that the period of constitutional monarchy had a positive significant effect on inflation.

The regression results of the slow-down, the recession and the break-up periods are presented in panel $\mathrm{B}$, panel $\mathrm{C}$ and panel $\mathrm{D}$, respectively, in Table 4 . While the war years caused an increase in inflation during the slow-down and the break-up periods, deflationary movements were seen during the recession period. However, the coefficient of war variable is statistically significant only in the slowdown period. Even though the highest inflation was seen in the Sultan Osman II period and the highest deflation was observed for the Sultan Mustafa I period in the slow-down era, their coefficients are not statistically significant. Moreover, the emprical results suggest that the periods of Sultans Osman III and Selim III in the recession era and those of Sultans Mustafa IV, Mahmud II and Mehmed Resad V in the break-up era had statistically significant effects on the acceleration in inflation. However, the Sultan Mustafa II period in the recession era and the Sultan Murad V period in the break-up era showed a statistically significant deflation. The highest inflationary movement was seen in the Sultan Osman III period in the recession era and the Sultan Mustafa IV period in the break-up era. Furthermore, the Sultan Mustafa II period in the recession era and the Sultan Murad V period in the breakup era showed statistically significant and the highest deflation. These results are very parallel to the panel A, column IV results in Table 4. Although the coefficients of the first-year variable are positive in both the recession and the break-up periods, they are statistically significant only during the recession period. The coefficient of the first-year variable showed a deflationary trend during the slow-down period, which is not statistically significant. Moreover, the results suggest that there was statistically significant acceleration in inflation during the period of constitutional monarchy as a result of the policies which were applied in this period.

Inflation could be observed due to either fiscal expansion or seigniorage revenue caused by the debasement of the Akçe in the long run. Hence, it is interesting to examine the source of inflation. Even though Spanish gold and silver were seen during these periods, we control these with the inflation dynamics, which is captured by the number of autoregressive lag orders. The empirical results of the debasement of the Akçe are presented in Table 5. The Table 6 results are based on the price indices expressed in grams of silver.

This paper first models the inflation dynamics using an AR procedure to capture the dynamics of the inflation. However, the inflation dynamics might be affected by other factors besides its own lags. If this is the case, then the AR model will be sub-optimum compared to a model that includes the features of the AR specification as well as other factors-transfer function analysis. It is quite difficult to identify the source of inflation, which is monetary (either an increase in silver supply or debasement) or fiscal expansion. ${ }^{3}$ We try to control the silver import with the data generating process that is captured by the AR process. Data on debasement is available. Thus, we claim that the variable that accounts for the debasement should capture the fiscal expansion. We recognize that this is a bold statement but it must be taken into consideration that this is an attempt to identify the fiscal policy rather than measure it. A government may use debasement (which causes inflation) to generate revenue as well. For example, Mankiw (1987) claims that as a government needs more resources to finance its spending, it increases its tax and seigniorage revenues simultaneously; therefore, debasement might be the source of inflation owing to fiscal expansions. 
It is worth mentioning that even though nominal prices increased, prices expressed in grams of silver stayed in a relatively narrow range because the changes in prices in this index depend on the change in grams of silver. Therefore, the difference between two prices gives us a change in the grams of silver, which might be used as a fiscal tool given that there was no persistent supply shock or gold imports at an accelerating rate. Thus, if the increase in price level is not due to a monetary factor, then it could be due to a fiscal factor. ${ }^{4}$ The empirical results of fiscal expansion are presented in Table 6. The negative coefficients in Table 5 represent debasement policies and the positive coefficients in Table 6 represent fiscal expansion policies.

Wars necessitate extra expenses; hence the need for extra sources to increase revenue. According to the empirical results that are presented in Tables 5 and 6 in column II of panel A, the war years showed anti-debasement acts, but the coefficient is not statistically significant. In addition, statistically significant fiscal expansions were seen in the war years. As a result, we can say that fiscal expansion rather than debasement was the main reason for inflation during the war years. Furthermore, the war years caused statistically significant anti-debasement movements in the recession and break-up periods. Although, debasement was seen due to the effects of war years in the slow-down period, its coefficient is not statistically significant. Even though the war variable had positive effects on the fiscal expansion in the three historical eras, the coefficient of the war variable is not statistically significant in the recession period. These results are presented in Tables 5 and 6 in column II of panel $B$, panel $C$ and panel D. Therefore, we can conclude that fiscal expansion was the main reason for inflation in the war years during the three historical eras. Debasement was the main inflationary policy to overcome the fiscal deterioration during the slow-down, the recession and the break-up periods. However, the coefficient of the slow-down period is not statistically significant. These statistics are presented in Table 5 in column III of panel A. Although the slow-down and the break-up periods showed fiscal expansion as a source of inflation, their coefficients are not statistically significant. A fiscal contraction was seen in the recession period, but its effect was not statistically significant. These results are represented in Table 6 in column III of panel A. The highest debasement was seen in the break-up period and the highest fiscal expansion was seen in the slow-down period.

Each sultan's inflationary acts can also be interpreted using the estimates reported in Tables 5 and 6 in column IV of panel A. The F-statistics suggest that each sultan adopted different debasement and fiscal policies and accelerated inflation differently. The F-statistics are 1.92 for the equality of sultan dummies in Table 5 and 1.64 for the equality of sultan dummies in Table 6. According to the empirical results, the periods of Sultans Mustafa I, Mehmed IV, Mahmud I, Abdulhamid I and Mahmud II showed statistically significant adaptation of debasement policies. Although most of the sultans' periods represented debasement, the highest acceleration of debasement was seen in the Sultan Süleyman II period, but its coefficient is not statistically significant. Pamuk (2000, pp. 204-217) argued that the greatest debasement was seen in the Sultan Mahmud II period of the Ottoman Empire. Hence, this result does not support our expectations. The estimates we report capture the debasement dynamic acceleration rather than the debasement itself. Hence, this could be the main reason for the differences between two studies.

The periods of Sultans Ahmed I, Mustafa IV and Mehmed Resad V showed statistically significant fiscal expansion policies and the highest fiscal expansion was seen in the Sultan Mustafa IV period. The periods of Sultans Mustafa II and Murad 


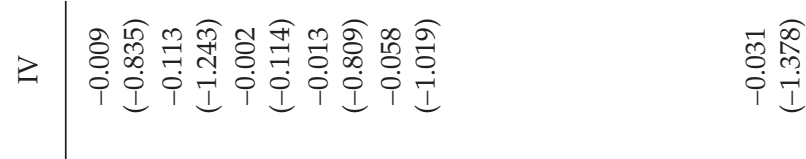

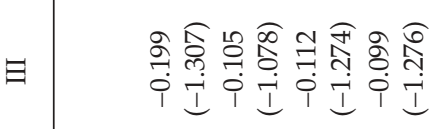

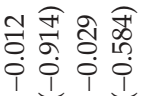

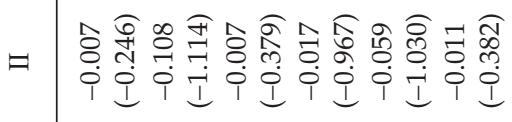

$-\quad \begin{aligned} & 0 \\ & 0 \\ & 0\end{aligned}$

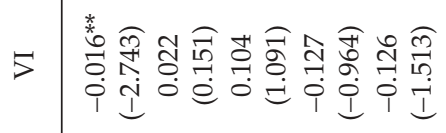
密蛋

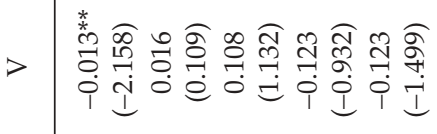

ì

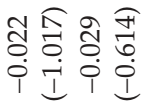

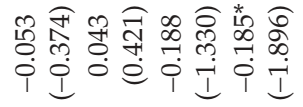

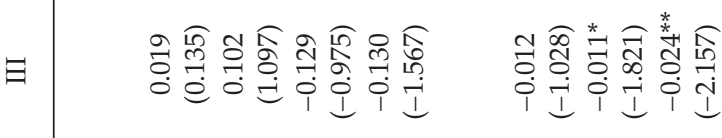

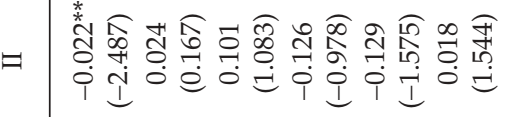

-

i i

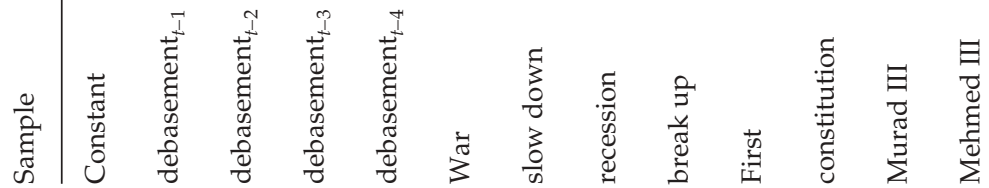




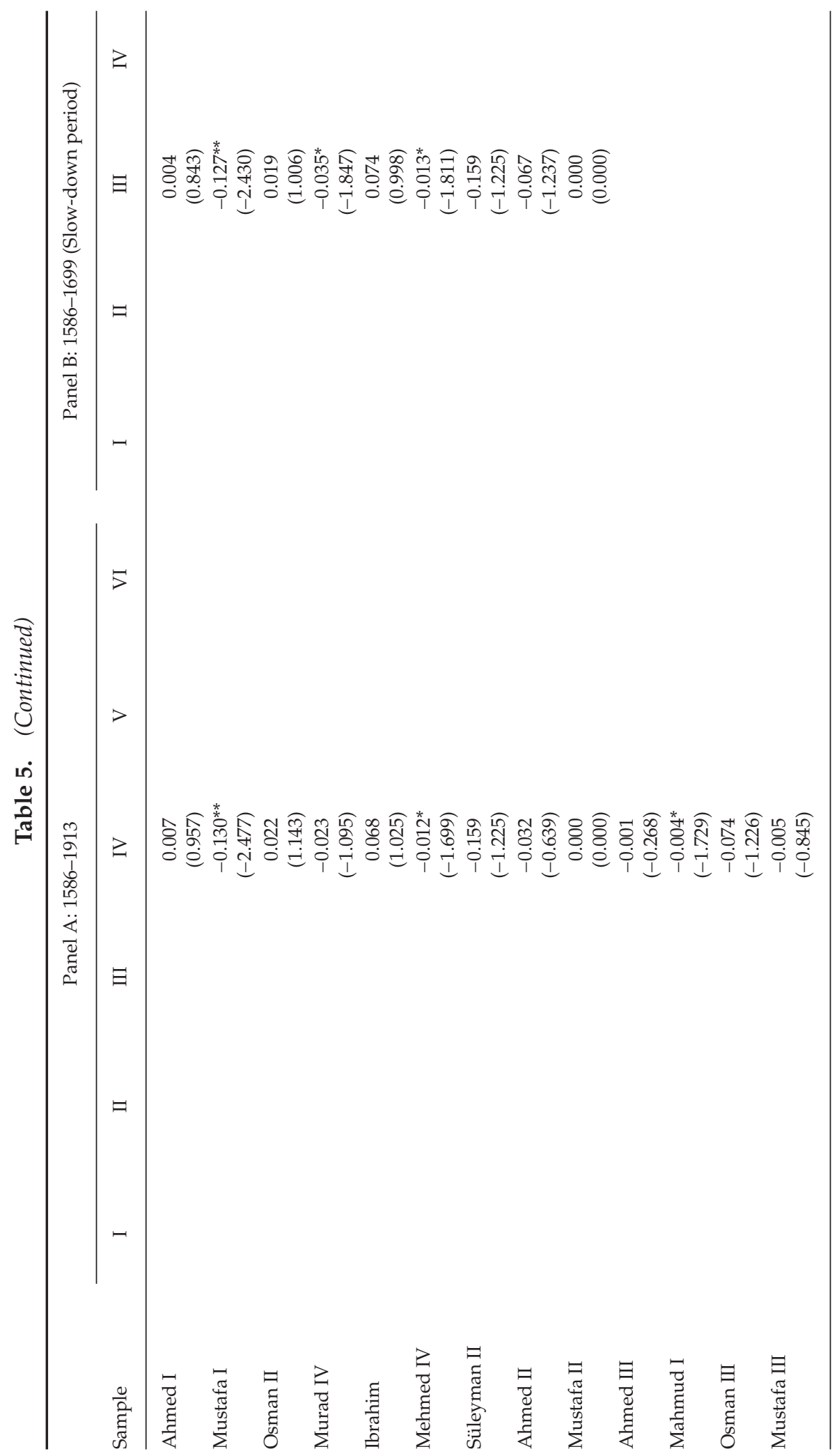


Inflation Dynamics in the Ottoman Empire 233

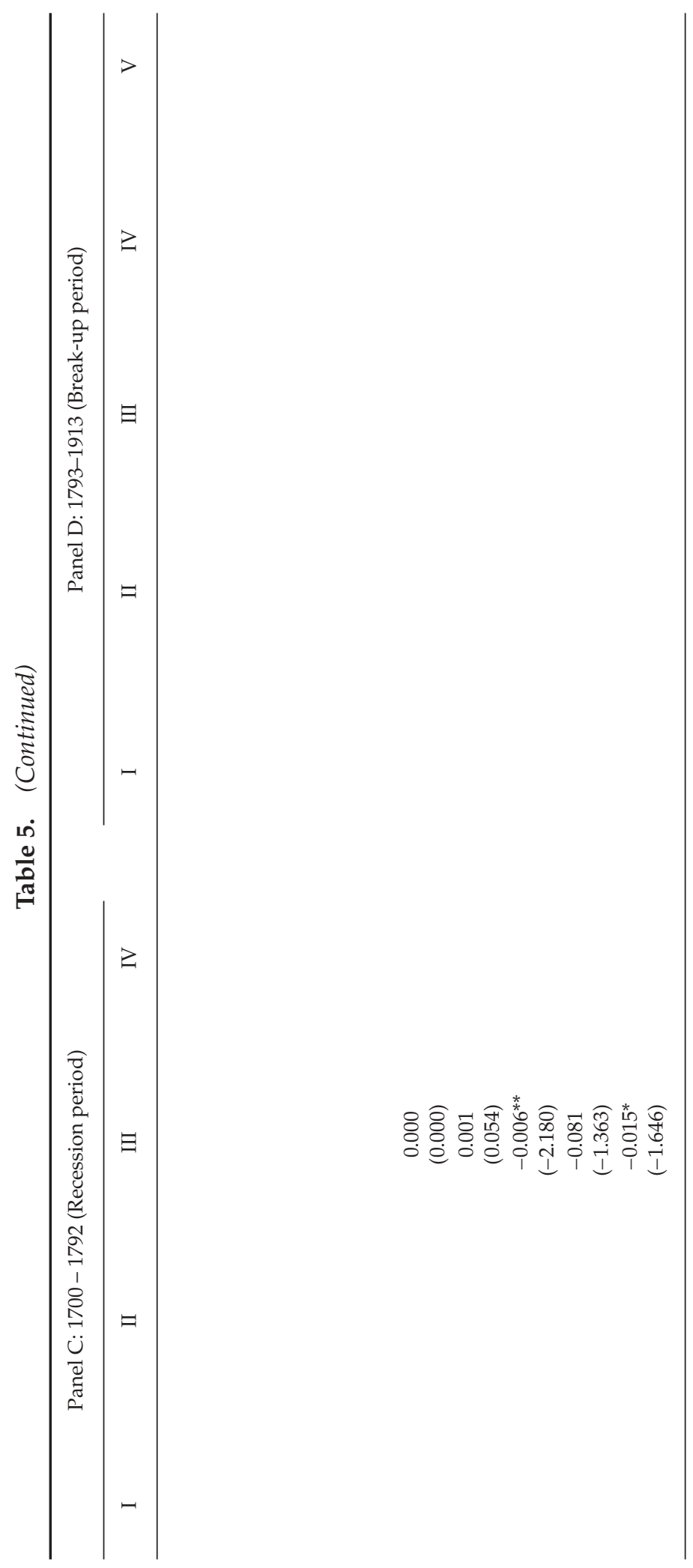




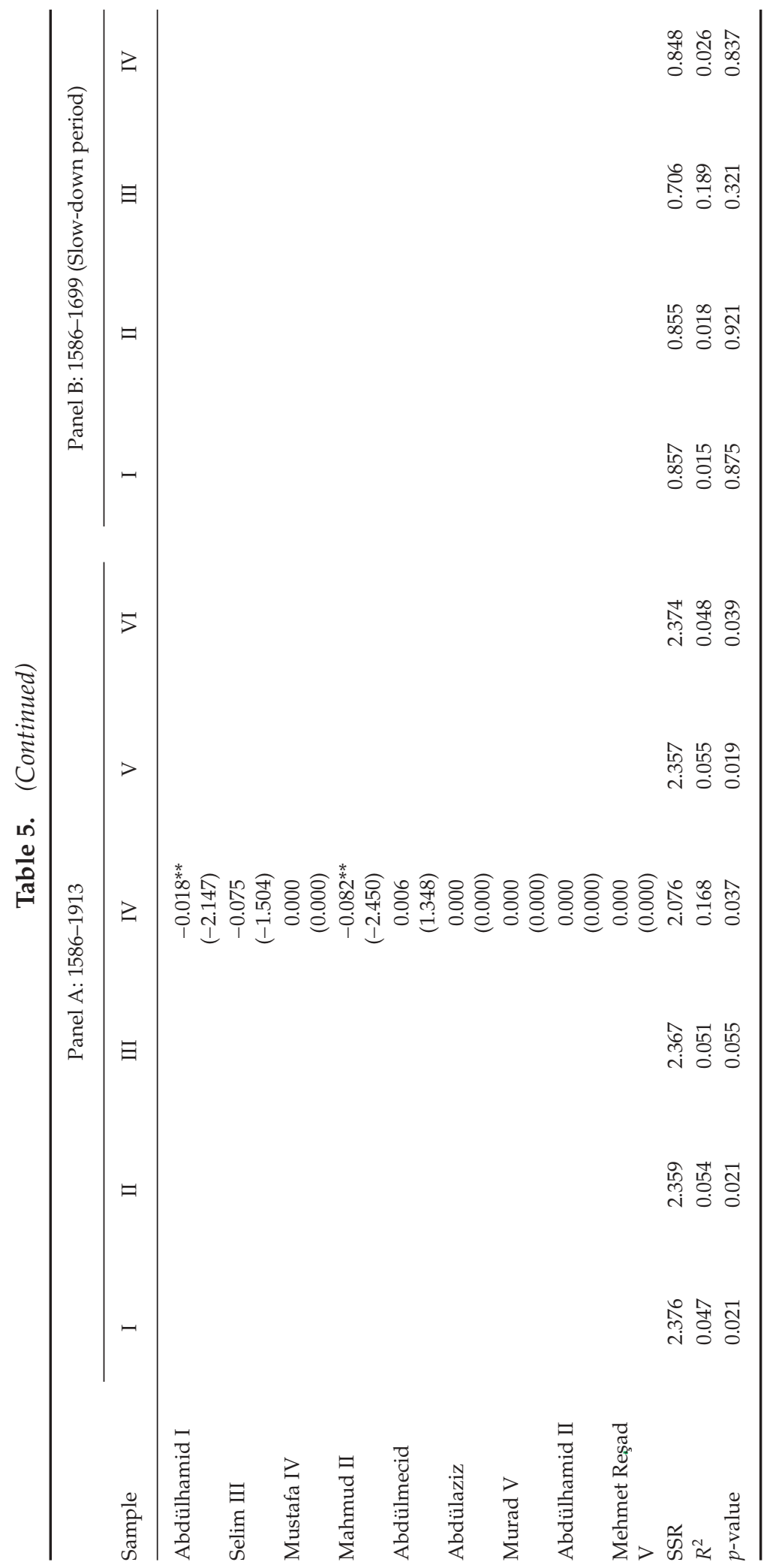


Inflation Dynamics in the Ottoman Empire 235

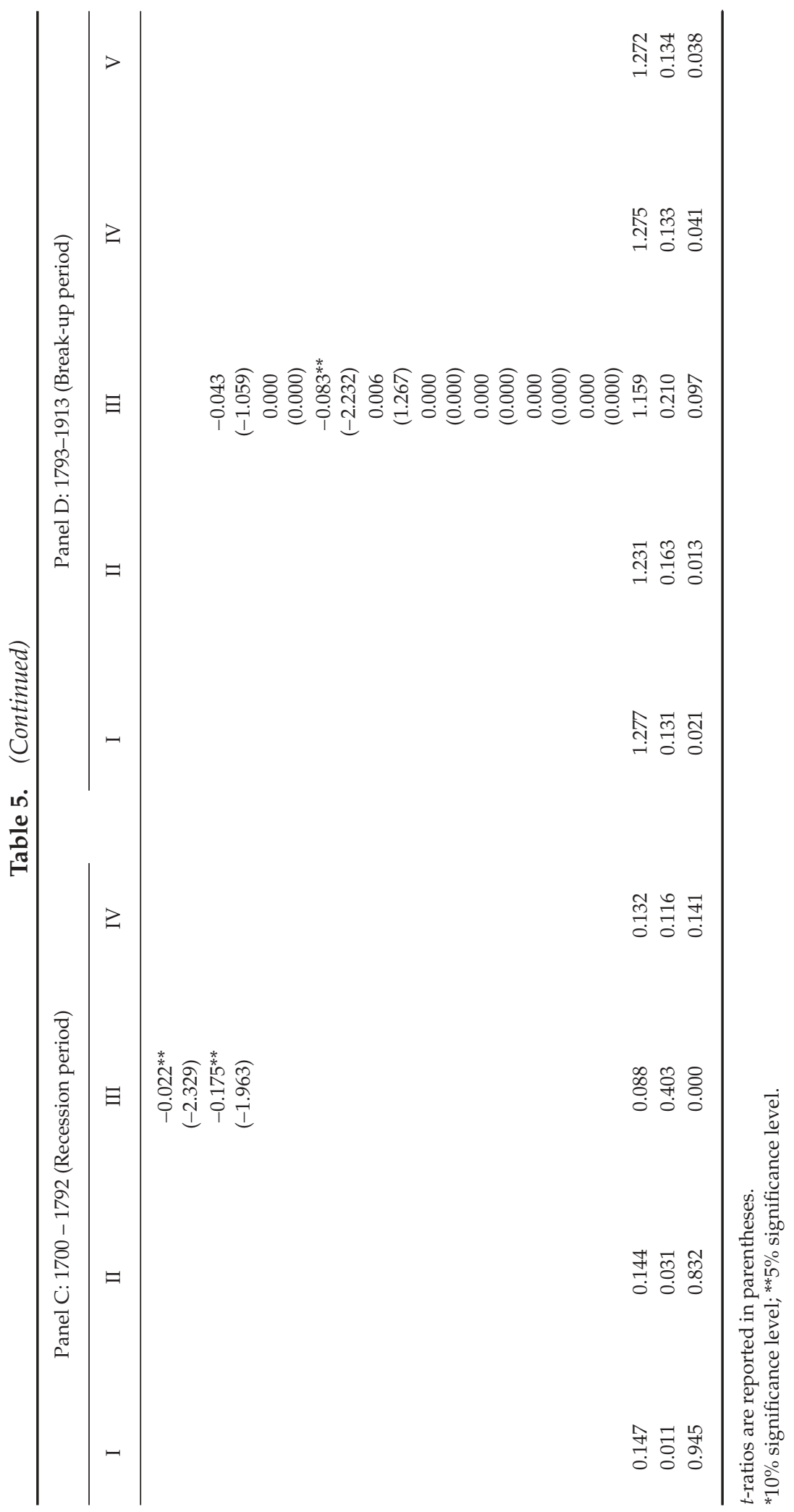




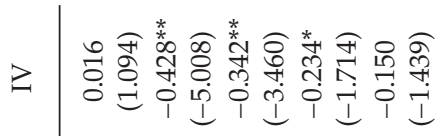

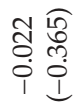

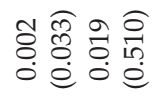

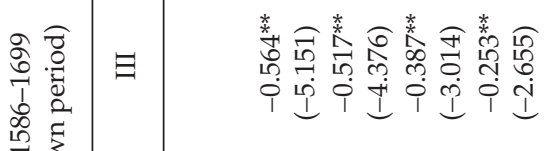

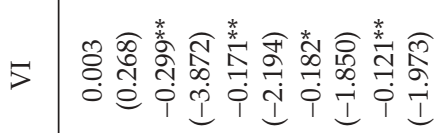

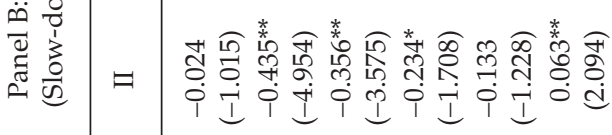

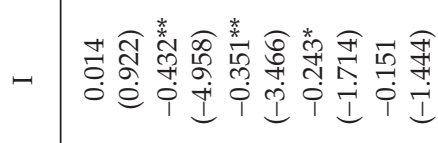

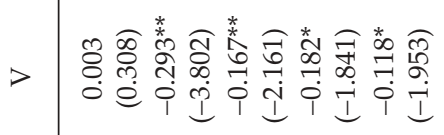

닝

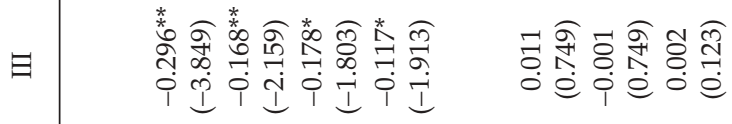

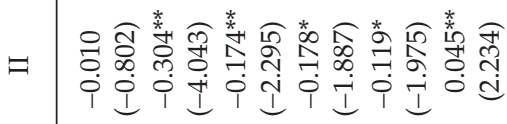

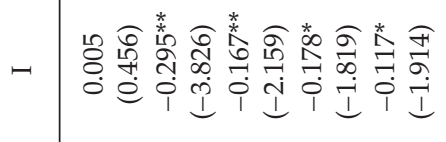

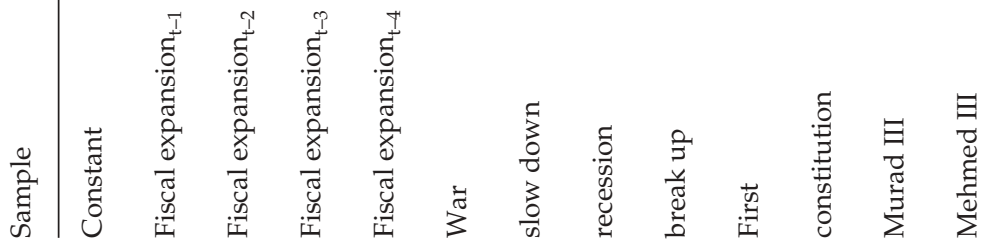


Inflation Dynamics in the Ottoman Empire 237

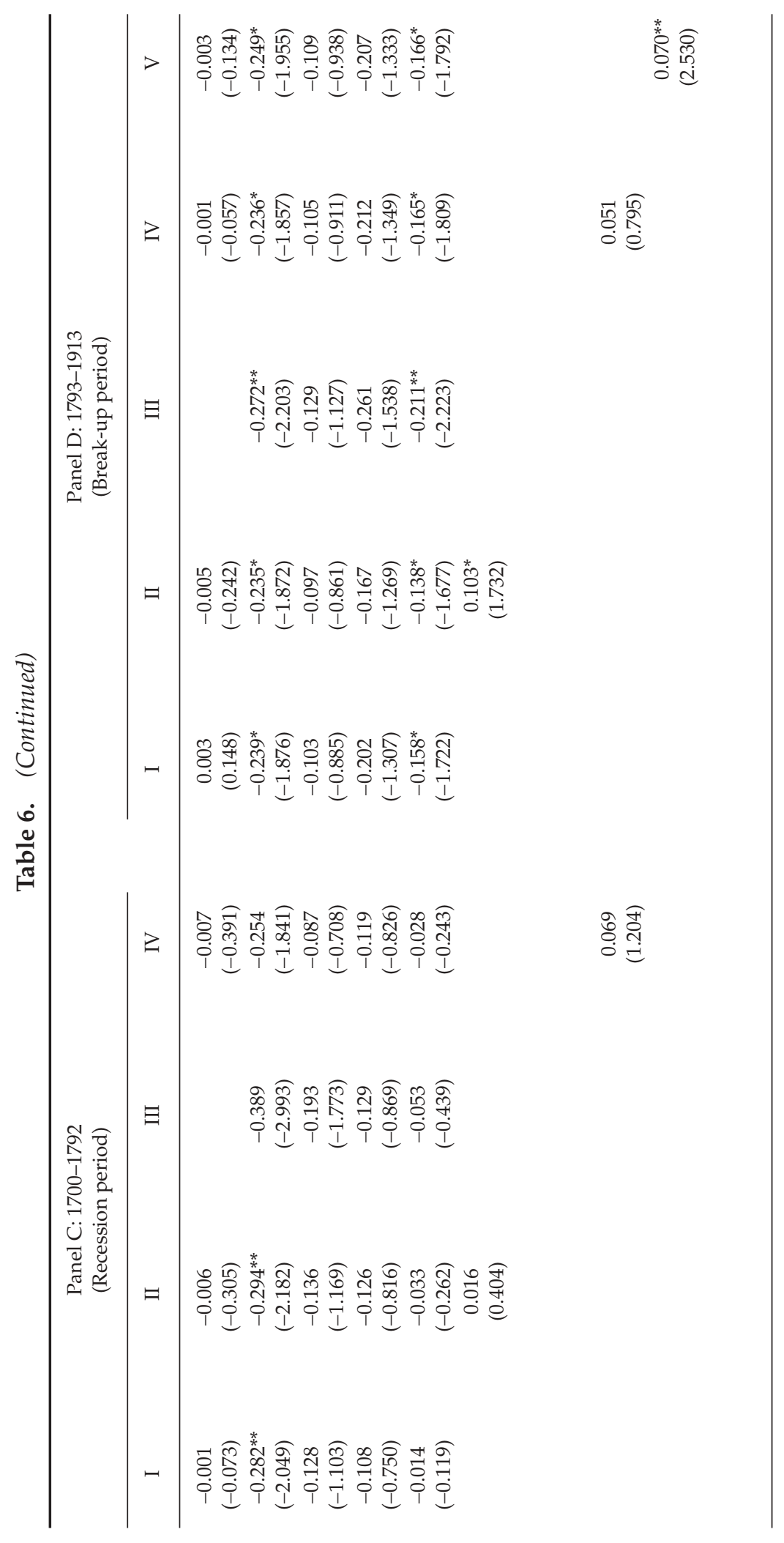




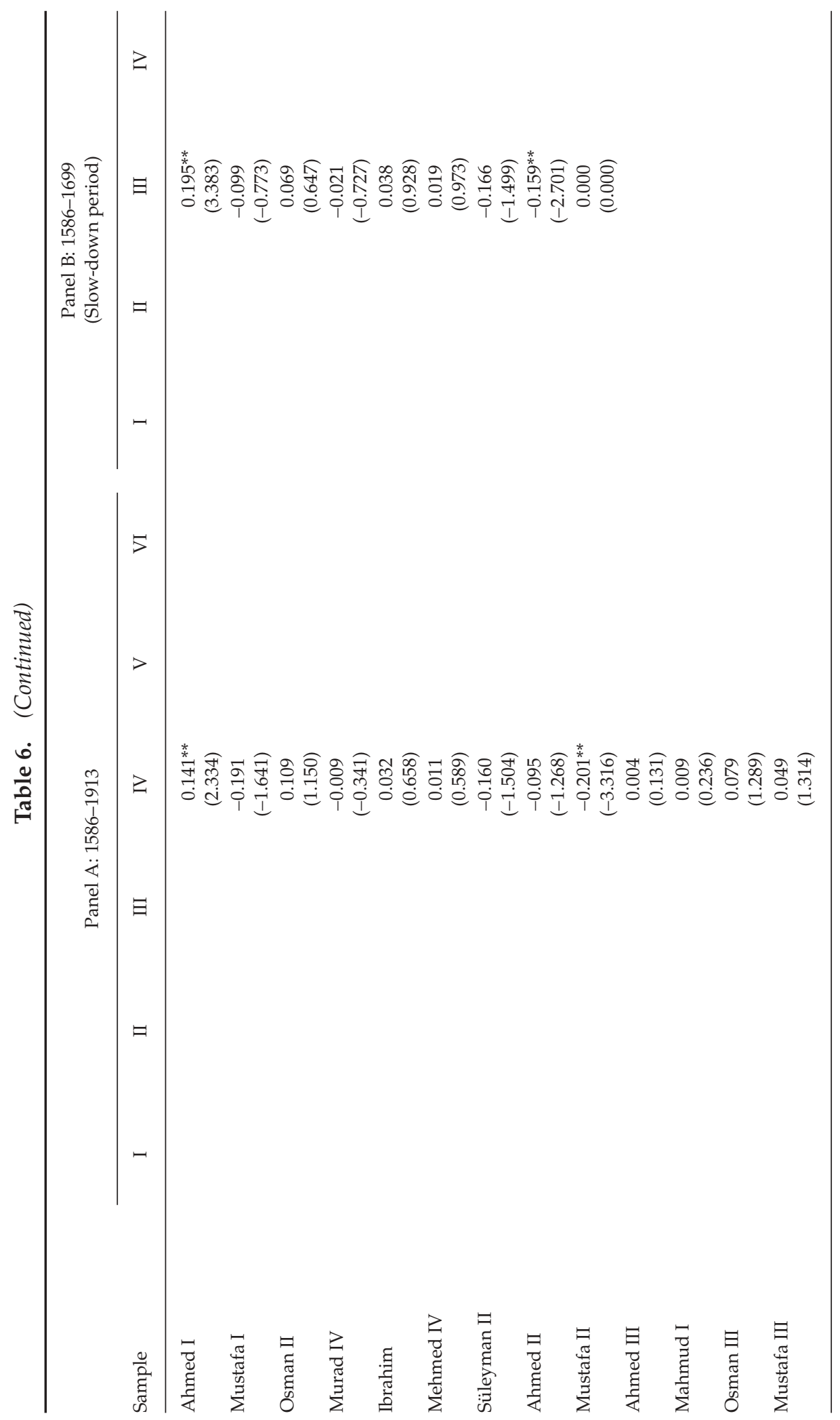


Inflation Dynamics in the Ottoman Empire 239

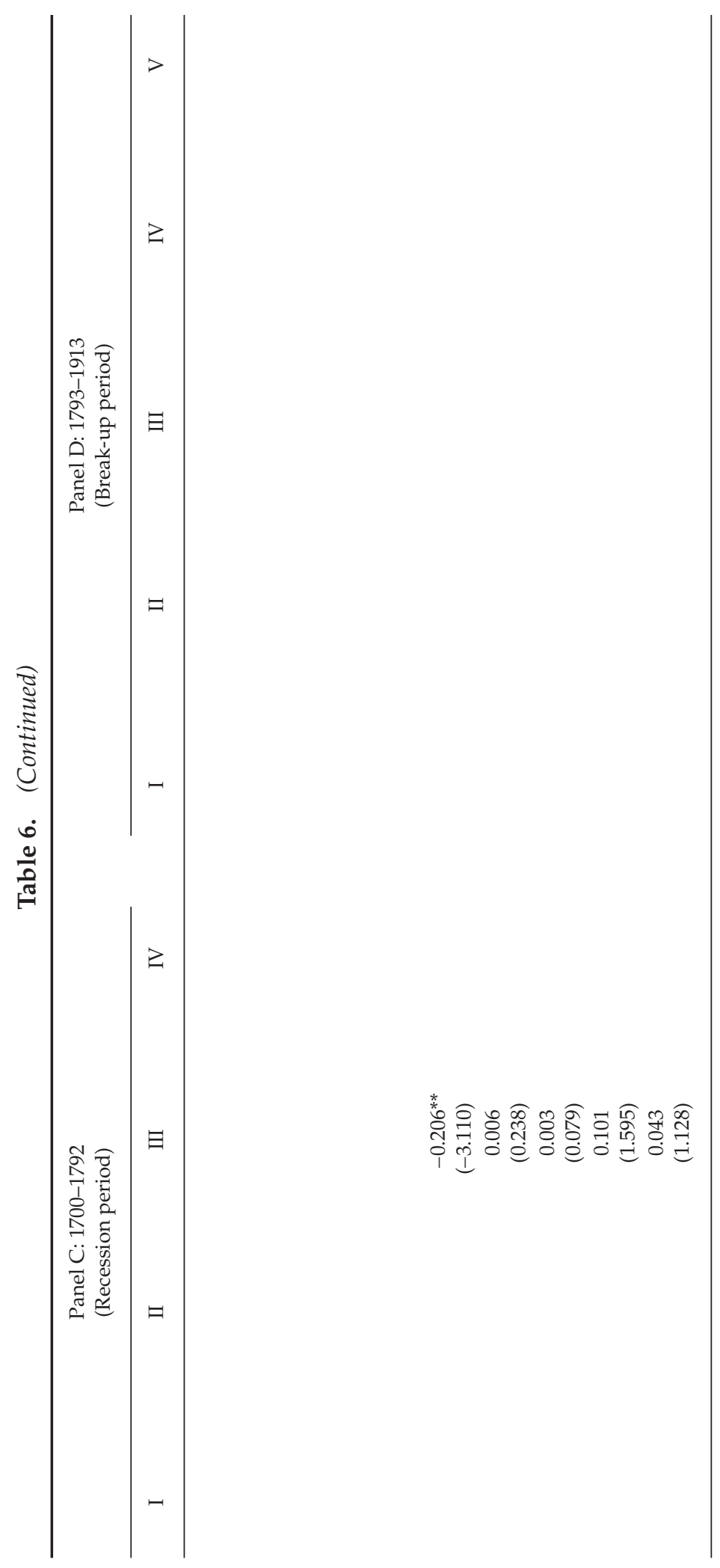




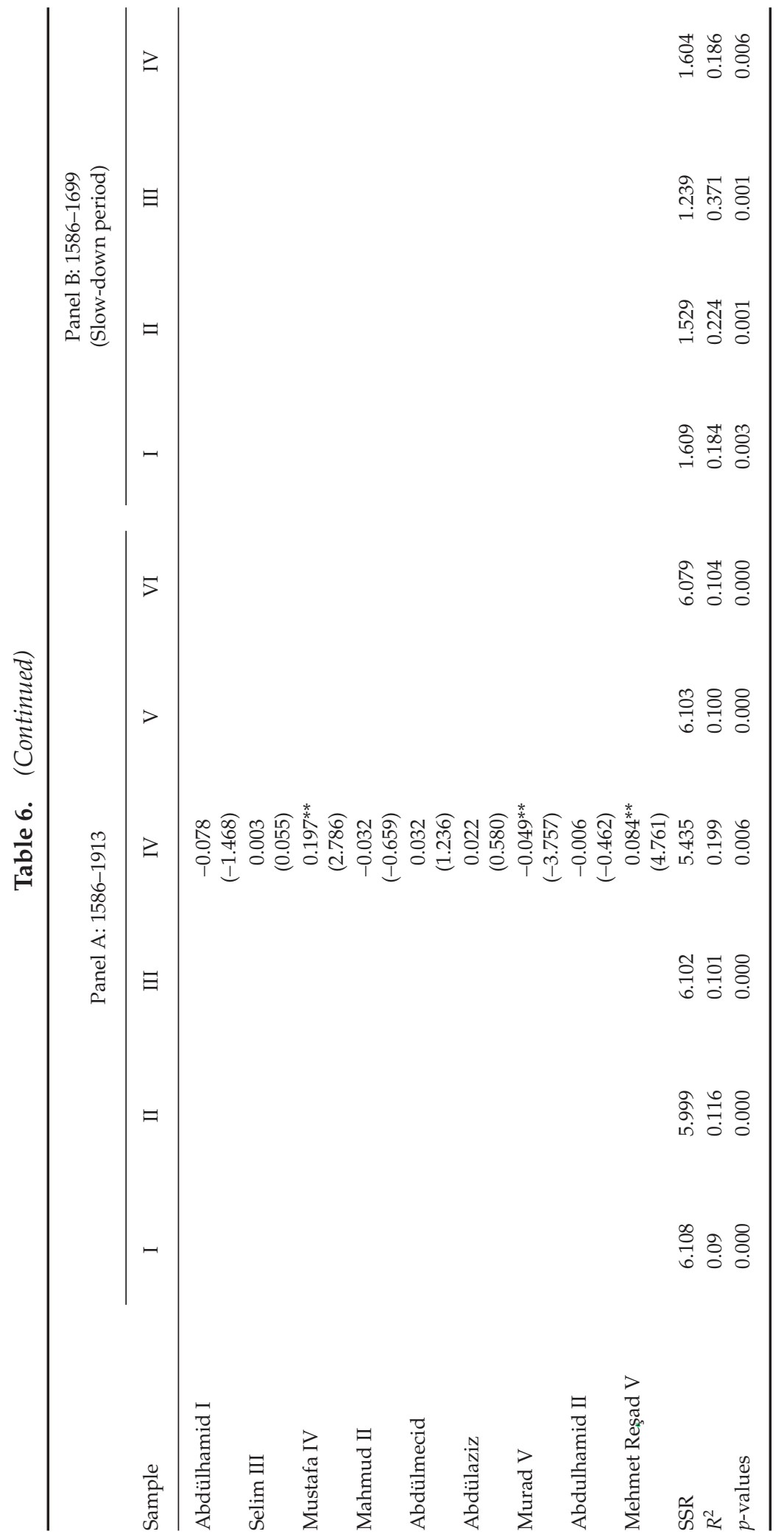


Inflation Dynamics in the Ottoman Empire 241

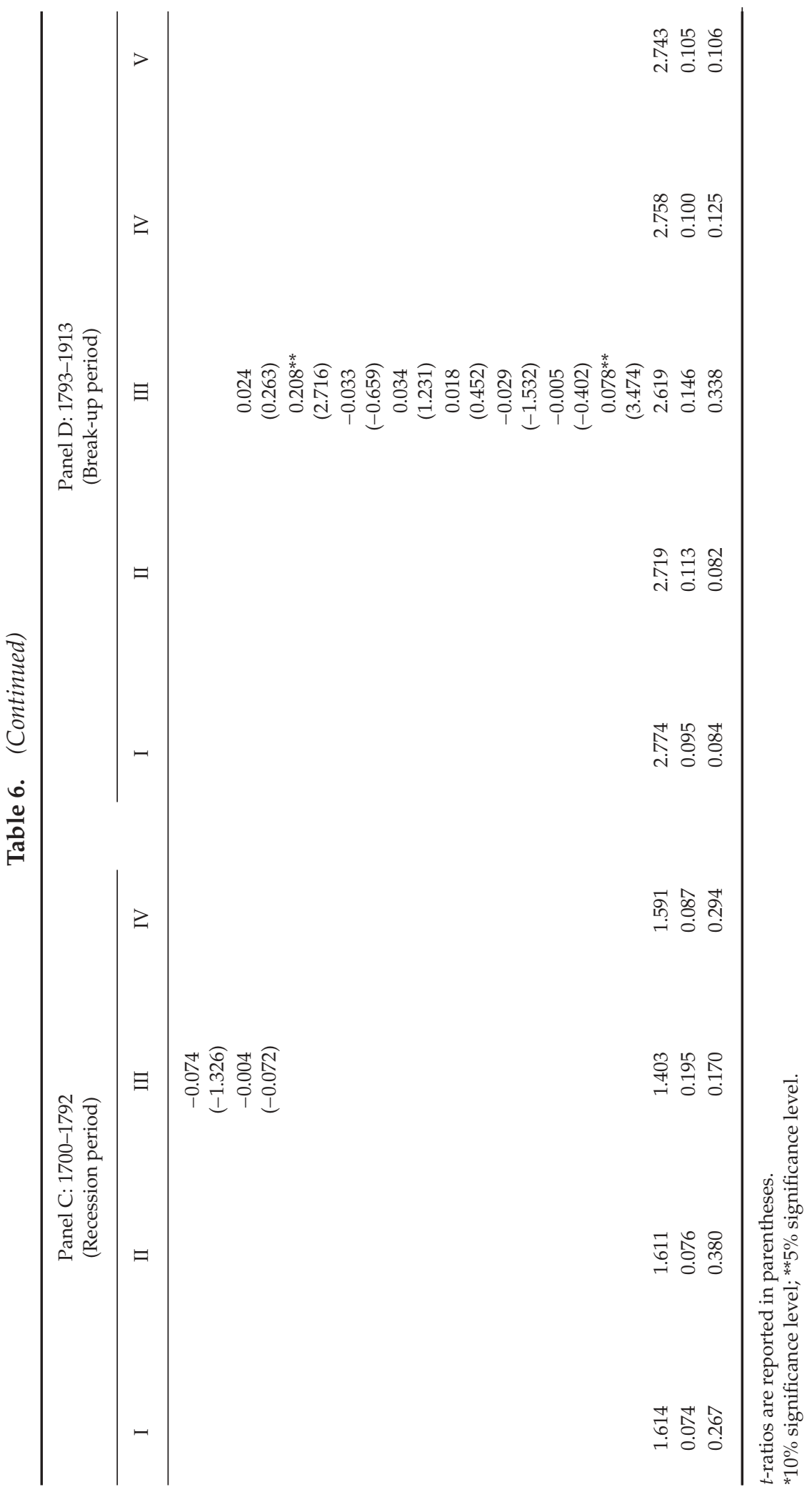


$V$, on the other hand, showed statistically significant fiscal contraction and the highest contraction can be seen in the Sultan Mustafa II period. While the periods of Sultans Mustafa I, Murad IV and Mehmed IV showed statistically significant debasement in the slow-down era, the periods of Sultans Mahmud I, Mustafa III, Abdulhamid I and Selim III showed statistically significant adoption of debasement policies in the recession era. The Sultan Mahmud II period had a statistically significant coefficient for the debasement in the break-up era. The highest debasement was seen in the Sultan Süleyman II period in the slow-down era, but its coefficient is not statistically significant. The Sultan Selim III period in the recession era and the Sultan Mahmud II period in the break-up era showed the highest statistically significant debasement. The highest and statistically significant fiscal expansion was seen in the Sultan Ahmed I period in the slow-down era. Although the Sultan Osman III period showed the highest fiscal expansion in the recession era, its coefficient is not statistically significant. The periods of Sultans Mustafa IV and Mehmed Resad $V$ showed statistically significant adoption of fiscal expansion policies and the highest fiscal expansion was seen in the Sultan Mustafa IV period in the breakup era. These empirical results are presented in Tables 5 and 6 in column III of panel B, panel C and panel D and they are quite parallel to the panel A (column IV) results in Tables 5 and 6 . The empirical evidence also suggests that each sultan chose debasement or fiscal expansion in the first year of his reign in order to win the goodwill of the soldiers and urban population so that he could stay on the throne. The results are presented in Tables 5 and 6 in Column V of Panel A. Also, the first year results (presented in Tables 5 and 6 in Column IV of Panel B, Panel C and Panel D) showed that both debasement and fiscal expansion were the reasons for inflation in the recession and break-up periods. Although debasement was seen in the slow-down period, fiscal contraction rather than fiscal expansion was seen in this era. However, the coefficients of the first year variable are not statistically significant. The period of constitutional monarchy showed statistically significant anti-debasement policies. The empirical results suggest that fiscal expansion was the main source of the acceleration in inflation during the period of constitutional monarchy. These results are presented in Tables 5 and 6 in column VI of panel A and in column V in panel D. Pamuk (2000, pp. 222-242) says that debasement ended after 1844 . Thus, our results are parallel to his findings.

Performing the regression analysis as an AR(4) process decreases the number of observations in the analyses as a result of the frequency of missing observations. Hence, we apply the AR(1) process for the inflation dynamics. In this case, we added a new dummy variable for the rise period (1478-1585). The basic results of the analyses were robust. ${ }^{5}$ The empirical evidence suggests that war accelerated inflation (as expected) and fiscal expansion rather than the debasement of the Akçe was the main reason for inflation. Moreover, the slow-down, the recession and the break-up periods affected inflation positively; both fiscal expansion and the debasement of the $A k c ̧ e$ were seen as sources of inflation during these three periods. The rise period, however, is associated with lower inflation. During the early years of the empire (that is the rise period), there was no need to rely on inflationary policies because the empire had some ways of increasing its revenue other than monetary or fiscal ones. However, it is important to note that even though the rise period did not show any debasement acts, we can see that the deflationary trend in inflation came from fiscal contraction in the rise period, probably more as a result of war spoils than to lower government spending. In spite of different inflationary policies during his reign. Each sultan accelerated inflation in the first 
year of his reign by the debasement of the $A k c ̧ e$ or fiscal expansion. Lastly, the constitutional monarchy period had a positively significant effect on inflation; however, fiscal expansion rather than the debasement of the $A k c ̧ e$ was the source of inflation in this period.

Note that the $R^{2}$ s are low for the estimated specifications. It is important to recognize that inflation series are not persistent and can be affected by various other factors that cannot be assessed with the currently available data sets. There might be various reasons why inflation series are not persistent. One is weather conditions, which affect the food supply. Another is the frequent occurrence of natural disasters like famine and earthquakes. In addition to natural causes, there are institutional reasons such as the non-existence of modern central banks and banking system, which means that the stock of money is not under the direct control of the government. Therefore, we can say that the lag values of the inflation are less likely to explain the behavior of inflation itself when compared to modern times and this decreases the $R^{2}$ s. Inflation can also be affected by other factors such as input prices, price controls, technological improvements, but we do not have data to assess their effects on inflation. Therefore, it is quite likely that the $R^{2} \mathrm{~s}$ will be low. We have provided the $p$-values of each specifications as an alternative to the $R^{2}$ s. For the full sample and sub-samples, most of the $p$-values are statistically significant. This result supports our inference gathered from the paper.

\section{Conclusion}

In this study, we have examined the dynamics of inflation in the Ottoman Empire during the 1586-1913 period. We focused on two main inflationary acts, fiscal expansion and seigniorage revenue as a result of the debasement of the Akçe in order to explain the behavior of inflation. We used a set of political and structural variables, the coefficients of which account for the change in the dynamics of inflation. We also extended our sample starting point to 1478 to apply the AR(1) process to examine dynamics of inflation. Accordingly, the empirical evidence suggests that the war years accelerated inflation as we had expected and fiscal expansion rather than debasement was the main inflationary policy used to cope with war expenses. Moreover, the slow-down, the recession and the break-up periods affected inflation positively. Both fiscal expansion and debasement were seen in these three periods as sources of inflation. However, deflationary movement was seen during the rise period due to fiscal contraction. Although each sultan implemented different inflationary policies in his reign, accelerated inflation due to debasement or fiscal expansion was characteristics of the first year. These results are consistent with the theory of Partisan PBC. Furthermore, the period of constitutional monarchy had a positively significant effect on inflation, but fiscal expansion rather than debasement can be seen as the main inflationary policy. This result is in conformity with our expectations because a fractionalized government raises inflation. It is important to note that there is not much difference between the $\mathrm{AR}(1)$ and the $\mathrm{AR}(4)$ process for examining the sources of the dynamics of the inflation since the signs of the coefficients of the variables are almost the same.

Some similarities can be observed between the dynamics of inflation in the Ottoman Empire and that of the Turkish Republic because they show similar economic structures. For example, high budget deficits and high inflation are the main characteristics of the two economies. Both fiscal expansion and monetary 
expansion are important sources of the dynamics of inflation in modern Turkey as it was in the Ottoman Empire.

Turkish economic history shows that budget deficits mainly arose on the expenditure side and the Central Bank provides a major part of the financing budget deficit in modern Turkey. After the devaluation of the Turkish lira, the Central Bank expands the money supply rapidly. Both fiscal expansion and monetary expansion lead to a increase in inflation. Metin (1998) analysed the relationship between inflation and the budget deficit for the Turkish economy and he found a positive relationship between them in Turkey. Metin (1998) also showed that financing budget deficit through monetary expansion affected inflation positively in Turkey. Atesoglu \& Dutkowsky (1995), however, showed that monetary expansion affected inflation positively in Turkey but they did not show the effect of financing budget deficit through monetary expansion. Metin (1995) also argued that fiscal expansion was a main determining factor for inflation in Turkey.

\section{Notes}

1. We would like to thank Anita Akkaşfor her valuable suggestions, and Mehdi Jelassi for his excellent research assistance.

2. The level of significance is $5 \%$, unless otherwise noted.

3. It is true that supply side disturbances might also affect the inflation process. However, persistent supply side shocks are not plausible especially for a such a long time span as considered here. Thus, we disregarded this aspect of inflation generation.

4. The source of the inflation could be due to other factors. However, we did not look at these factors. There are two reasons for this. First, these variables not likely to be persistent; for example supply side shocks stemming from weather conditions are not expected to persist one year after another year for a long period of time. Second, reliable data on this type of variables are not available for a such long period of time.

5. These estimates are available from the authors upon request.

\section{References}

Alesina, A. \& Roubini, N. (1992) Political cycles in OECD economies, Review of Economic Studies, 59, pp. 663-688.

Alesina, A. \& Sachs, J. (1988) Political parties and the business cycle in the United States 1948-1984, Journal of Money, Credit and Banking, 20, pp. 63-82.

Arce, M. \& Daniel, G. (1994) Coalition dynamics, social norms, and the persistence of inflation, Quarterly Review of Economics and Finance, 34, pp. 145-157.

Atesoglu, H. S. \& Dutkowsky, D. H. (1995) Money, output and prices in Turkey, Applied Economics Letters, 2, pp. 38-41.

Barkan, Ö. L. (1975) The price revolution of the sixteenth century: a turning point in the economic history of the Near East, International Journal of Middle East Studies, 6, pp. 3-28.

Bolbol, A. A. (1999) Seigniorage, dollarization and public debt: the Lebanese Civil War and recovery experience 1982-97, World Development, 27, pp. 1861-1873.

Braudel, F. \& Spooner, F. (1967) Prices in Europe from 1450 to 1750, in The Cambridge Economic History of Europe, Vol. IV. Cambridge: Cambridge University Press.

Enders, W. (2000) Applied Econometric Time Series. New York: John Wiley.

Ferguson, N. (1996) Constraints and room for manoeuvre in the German inflation of the early 1920s, Economic History Review, 49, pp. 635-666.

Haynes, S. E. \& Stone, J. A. (1990) Political models of the business cycle should be revived, Economic Inquiry, 28, pp. 442-465.

Hibbs, D. A. (1977) Political parties and macroeconomic policy, American Political Science Review, 71, pp. 1467-1487.

Mankiw, N. G. (1987) Optimal collection of seigniorage: theory and evidence, Journal of Monetary Economics, 20, pp. 327-341. 
Metin, K. (1995) An integrated analysis of Turkish inflation, Oxford Bulletin of Economics and Statistics, 57, pp. 513-533.

Metin, K. (1998) The relationship between inflation and the budget deficit in Turkey, Journal of Business and Economic Statistics, 16, pp. 412-422

Pamuk, Ş. (1997) In the absence of domestic currency: debased European coinage in the seventeenthcentury Ottoman Empire, Journal of Economic History, 57, pp. 345-366.

Pamuk, Ş. (2000) A Monetary History of the Ottoman Empire. Cambridge: Cambridge University Press.

Roubini, N. \& Sachs, J. (1989) Political and economic determinants of budget deficits in the industrial democracies, European Economic Review, 33, pp. 903-938.

Schumpeter, J. A. (1954) History of Economic Analysis. Oxford: Oxford University Press, pp. 311-312.

\section{Supplement to "Inflation Dynamics and its Sources in The Ottoman Empire: 1586-1913"}

This supplementary material provides additional empirical evidence that is not reported in the original paper and is available upon request from the author. 